\title{
FUTURE-SE S.A.: O “PROGRAMA BOLSONARISTA”PARA AS INSTITUIÇÕES FEDERAIS DE ENSINO SUPERIOR (IFES).
}

\author{
FUTURE-SE S.A.: EL "PROGRAMA BOLSONARISTA" PARA INSTITUCIONES \\ FEDERALES DE EDUCACIÓN SUPERIOR (IFES).
}

\section{FUTURE-SE S.A.: THE “BOLSONARISTA PROGRAM” FOR FEDERAL HIGHER EDUCATION INSTITUTIONS (IFES).}

DOI: http://dx.doi.org/10.9771/gmed.v11i3.35165

\begin{abstract}
Marcelo Lira Silva ${ }^{1}$
Resumo: Objetiva-se, com este ensaio, examinar e apresentar um estudo sistemático do "Programa Institutos e Universidades Inovadoras: Future-se", apresentado pelo Ministro da Educação, Abraham Bragança de Vasconcellos Weintraub (1971 - ), no dia 17 de junho de 2019, de tal forma a entendê-lo, a partir de dois movimentos históricos que se retroalimentam: 1 . Trata-se de um projeto que integra a agenda político-econômica e sociocultural do neoliberalismo-flexível, em curso no Brasil, desde os anos de 1990; 2. Trata-se de um projeto que integra a agenda autocrático-regressiva do Golpe de Estado soft de 2016, do qual Jair Messias Bolsonaro (1955 - ) emergiu enquanto principal representante político-econômico e sociocultural. Nesse sentido, o programa integra dois movimentos históricos, a partir dos quais se poderia reconstituir seus princípios e fundamentos, bem como, seu sentido e significado, como forma de se constituir algum nível de entendimento, acerca da concepção da política educacional bolsonarista. Assim sendo, seria equivocado analisar o programa de forma em-si-mesmada, sem estabelecer os nexos históricos e causais que o fundamentam, objetiva e subjetivamente. O "Programa Bolsonarista" é, por um lado, um sistema complexo de cooptação de quadros dirigentes e intelectuais das IFES; por outro, e, de forma complementar, é um sistema de privatização de seus processos administrativo-organizativos, financeiro e didático-pedagógico. Assim, a Minuta de Projeto Lei apresentada pelo ministro da educação, além de ser parte constitutiva de um Programa de Governo de extrema-direita, que dialoga diretamente com o fascismo, integra a agenda do capital-imperialismo, neoliberal-flexível, como forma de ressubordinação, tanto dos Estados nacionais periféricos, dependentes, subordinados e associados ao capital-imperialismo, quanto das classes trabalhadoras e demais classes subalternas de tais países. Nesse sentido, entender-se-á ser mais apropriado denominar o projeto apresentado de "Programa Bolsonarista", na medida em que é expressão de um movimento histórico, no e a partir do qual as classes dominantes brasileiras cooptaram o fascismo, para encaminhar "pelo alto", uma agenda autocráticoregressiva, marcadamente, antipopular e antidemocrática. Assim sendo, o ensaio apresentado se estruturará, metodologicamente, a partir de uma análise do processo histórico, demarcado pela constituição e decadência da chamada Nova República (1988-2016), bem como de seus principais sujeitos históricos, de tal forma a comparálo com o ordenamento jurídico do país, como forma de se constituir algum nível de entendimento acerca da política educacional expressa no e pelo "Programa Bolsonarista".
\end{abstract}

Palavras-chave: Política Educacional - Programa Bolsonarista - Estado de Exceção.

Abstract: The aim of this essay is to examine and present a systematic study of the "Program Innovative Institutes and Universities: Future-se", presented by the Minister of Education, Abraham Bragança de Vasconcellos Weintraub (1971 -), on June 17. in 2019, in such a way as to understand it, from two historical movements that feed on each other: 1 . It is a project that integrates the political-economic and socio-cultural agenda of flexible neoliberalism, underway in Brazil, since the 1990s; 2. It is a project that is part of the autocratic-regressive agenda of the 2016 coup d'etat soft, from which Jair Messias Bolsonaro (1955 -) emerged as the main political-economic and socio-cultural representative. In this sense, the program integrates two historical movements, from which one could reconstitute its principles and foundations, as well as their meaning and meaning, as a way of constituting some level of understanding about the conception of the 
educational policy. Therefore, it would be wrong to analyze the program on its own, without establishing the historical and causal links that underlie it, objectively and subjectively. The "Bolsonarista Program" is, on the one hand, a complex system of co-optation of IFES leadership and intellectuals; on the other, and complementarily, it is a system of privatization of its administrative-organizational, financial and didactic-pedagogical processes. Thus, the Draft Bill presented by the Minister of Education, besides being a constitutive part of a far-right Government Program, which dialogues directly with fascism, is part of the agenda of neoliberal-flexible capitalimperialism, as a way of resubordination, both of the peripheral, dependent, subordinate and associated national states associated with capital-imperialism, as well as of the working classes and other subordinate classes of such countries. In this sense, it will be understood to be more appropriate to call the project presented the "Bolsonarista Program", as it is an expression of a historical movement, in and from which the Brazilian ruling classes co-opted fascism, to refer "through high, "a markedly unpopular and undemocratic autocratic-regressive agenda. Thus, the presented essay will be methodologically structured based on an analysis of the historical process, demarcated by the constitution and decay of the so-called New Republic (1988-2016), as well as its main historical subjects, in order to compare it. with the country's legal system, as a way of constituting some level of understanding about the educational policy expressed in and by the "Bolsonarista Program".

Keywords: Educational Policy - Program Bolsonarista - State of Exception.

Resumen: El objetivo de este ensayo es examinar y presentar un estudio sistemático de lo "Programa Institutos y Universidades Innovadores: Future-se", presentado por el Ministro de Educación, Abraham Bragança de Vasconcellos Weintraub (1971 -), el 17 de junio. en 2019, de tal manera que lo entienda, a partir de dos movimientos históricos que se alimentan entre sí: 1. Es un proyecto que integra la agenda político-económica y sociocultural del neoliberalismo flexible, en curso en Brasil, desde 1990s; 2. Es un proyecto que forma parte de la agenda autocrática regresiva del golpe de estado de 2016, del cual Jair Messias Bolsonaro (1955 -) surgió como el principal representante político-económico y sociocultural. En este sentido, el programa integra dos movimientos históricos, a partir de los cuales uno podría reconstituir sus principios y fundamentos, así como su sentido y significado, como una forma de constituir cierto nivel de comprensión sobre la concepción de la política educativa. Por lo tanto, sería un error analizar el programa por sí solo, sin establecer los vínculos históricos y causales que lo subyacen, objetiva y subjetivamente. El "Programa Bolsonarista" es, por un lado, un complejo sistema de cooptación de líderes e intelectuales de IFES; por el otro, y complementariamente, es un sistema de privatización de sus procesos administrativos-organizativos, financieros y didáctico-pedagógicos. Por lo tanto, el Proyecto de Ley presentado por el Ministro de Educación, además de ser parte integrante de un Programa de Gobierno de extrema derecha, que dialoga directamente con el fascismo, forma parte de la agenda del imperialismo de capital flexible neoliberal. resubordinación, tanto de los estados nacionales periféricos, dependientes, subordinados y asociados con el imperialismo capitalista, como de las clases trabajadoras y otras clases subordinadas de dichos países. En este sentido, se entenderá que es más apropiado llamar al proyecto presentado el "Programa Bolsonarista", ya que es una expresión de un movimiento histórico, en y desde el cual las clases dominantes brasileñas cooptaron el fascismo, para referirse "a través de alto ", una agenda marcadamente impopular y antidemocrática regresiva autocrática. Por lo tanto, el ensayo presentado se estructurará metodológicamente en función de un análisis del proceso histórico, delimitado por la constitución y la decadencia de la llamada Nueva República (1988-2016), así como sus principales temas históricos, para compararlo. con el sistema legal del país, como una forma de constituir cierto nivel de comprensión sobre la política educativa expresada en y por el "Programa de Bolsonarista".

Palabras clave: Política Educativa - Programa Bolsonarista - Estado de Excepción.

\section{Neoliberalismo-flexível e conhecimento reificado: ciência e tecnologia como dominação.}

Pode-se definir o neoliberalismo-flexível, como a mais avançada política-econômica e sociocultural do capital-imperialismo, sendo que uma de suas bases estruturantes encontra-se na concepção de ciência e tecnologia como dominação, e, portanto, como uma de suas principais ideologias. Deste modo, trata-se de uma resposta, objetiva e subjetiva, encontrada pelo capital, para fazer frente à crise estrutural de valorização, iniciada nos anos de 1970. O neoliberalismo-flexível, enquanto ideologia global regressiva forjou um complexo sistema de dominação autocrático, estruturado em círculos concêntricos. Nestes termos, por um lado, trata-se de uma política-econômica, de caráter global, a partir da qual o epicentro do capital-imperialismo impõe aos demais Estados nacionais a flexibilização de suas leis e instituições; por outro, a flexibilização das leis e instituições 
levam a fragilização e/ou destruição das próprias bases dos Estados nacionais periféricos. Trata-se de um redesenho coercitivo do movimento desigual e combinado do desenvolvimento do capitalismo mundial contemporâneo, a partir do qual o epicentro do capital-imperialismo controla e (re)subordina o complexo periférico que se constituiu, ao longo do século XX. Estes dois movimentos acabaram por instituir processos cada vez mais agudos de periferização da periferização, estabelecendo centros periféricos complexos, dentro das próprias periferias, de tal forma a hierarquizar os tipos, as formas e os conteúdos de dominação e difusão da ideologia global regressiva, como forma de legitimar políticas que dialogam, cultivam e estimulam o ressurgimento do fascismo. Nesse sentido, o Brasil do século XXI pode ser entendido enquanto um centro periférico complexo, sendo que suas decisões políticoeconômicas e socioculturais alteram profundamente a dinâmica da região.

A crise estrutural do capital, aberta nos anos de 1970, conduziu o capital-imperialismo a adoção de uma política-econômica e sociocultural autocrática e regressiva, estruturada na e pela concepção de ciência e tecnologia como ideologia, com o objetivo de resgatar a capacidade de valorização, via financeirização do capital. Assim, o processo de reprodução ampliada do capital deslocou-se do processo produtivo da riqueza social, para o campo da financeirização e rentismo. Tal deslocamento implicou na recomposição tanto do bloco bistórico, quanto dos blocos no poder nacionais, governados pelas grandes corporações financeiro-rentistas, que passaram a conduzir tanto a política-econômica, quanto sociocultural, a partir de círculos concêntricos, administrados e governados pelo capital-imperialismo, de maneira direta, via intervenção militar, e/ ou de maneira indireta, via imposição de agendas políticoeconômicas e socioculturais autocrático-regressiva, fundamentadas no neoliberalismo-flexível. Assim, os ideólogos do neoliberalismo-flexível trataram de forjar um conceito eufêmico, para positivar um processo abertamente autocrático-regressivo, ao qual denominaram globalização. A ideologia da globalização fora difundida e assimilada de forma positivada, de tal forma a associá-la a ideia de modernidade e fim das fronteiras estabelecidas pelos Estados nacionais, como forma de forjar o convencimento acerca da flexibilização tanto do capital, quanto do trabalho. Tratar-se-ia de uma ideia de liberdade programada. Por um lado, a dominação por círculos concêntricos, obrigou os países periféricos a desregulamentar suas economias, vulnerabilizando-as, de tal forma a flexibilizar e/ou abolir toda e qualquer legislação que impedisse o movimento de valorização do capital, em escala global; por outro, obrigou tais países a desregulamentar e/ou abolir toda e qualquer legislação, capaz de garantir direitos civis, políticos e sociais mínimos, como forma de desestruturar e/ou criminalizar as organizações relativamente autônomas das classes trabalhadoras ${ }^{2}$, tais como sindicatos, movimentos sociais e partidos de esquerda. Tratar-se-ia de um movimento global de plutocratizaçãooligarquização, imposta pelo capital-imperialismo, via dominação por círculos concêntricos.

Deve-se destacar que o capital é expressão de uma relação social intrinsecamente contraditória, na medida em que se reproduz de forma ampliada, a partir da exploração social do trabalho produtivo. As vias de capitalismo hipertardio dependeram da estruturação de um conjunto de estatais, responsáveis por estruturar, diversificar e alavancar as economias nacionais periféricas. Portanto, ao longo do século XX, nas mais variadas experiências de desenvolvimento do capitalismo 
hipertardio, dependentes, subordinados e associados, as empresas estatais foram responsáveis por consolidar tipos específicos e distintos de capitalismo. A (re)subordinação do complexo sistema periférico capitalista, exigia, além da flexibilização do binômio capital-trabalho, o controle da principal variável de desenvolvimento do capitalismo periférico, via privatização das empresas estatais. Tratarse-ia de transferir o controle e a administração da infraestrutura nacional, a partir da qual se constituiu a ideia e o princípio mínimo de república e democracia formal liberal-representativa, para o capitalimperialismo. Assim, a gestão do patrimônio público (água; energia; minérios; petróleo; instituições públicas, voltadas a diminuição das desigualdades sociais...), passou a ser a principal variável a ser controlada pelo capital-imperialismo, seja de maneira direta, via privatização, seja de maneira indireta, via transferência de gestão para uma empresa privada, denominada de forma eufêmica de Organização Social (OS).

Enquanto ideologia global, o neoliberalismo-flexível converteu-se em processo de regressão cultural (SILVA, 2014), na medida em que, para se difundir necessitava cooptar as frações de classes de direita e extrema-direita, como forma de legitimar governos autocráticos, a partir da instrumentalização de regras técnicas de democracias puramente formais, e, viabilizar a política de valorização do capital. Se no seu nascedouro o liberalismo era uma cultura política revolucionária e emancipatória, fundamentada na defesa das liberdades individuais e direitos civis (SILVA, 2012); no último quartel do século $\mathrm{XX}$, abandonou seus fundamentos culturais e políticos emancipatórios e civilizatórios, e, converteu-se, única e exclusivamente, em ideologia autocrático-regressiva. Talvez, a expressão mais nítida desse processo seja a aporia, difundida pelos ideólogos do neoliberalismoflexível, como forma de cooptar a direita e a extrema-direita: "Sou liberal na economia e conservador nos costumes"! Trata-se de uma contradição em termos, na medida em que o liberalismo defendia a liberdade econômica, por entendê-la, única e exclusivamente, enquanto expressão das liberdades individuais e garantia dos direitos civis. A liberdade econômica, no âmbito do liberalismo clássico, é expressão das liberdades individuais, portanto, parte intrínseca da moral deontológica liberalburguesa, de tal forma que seria impossível descolá-la da concepção de sociedade e moral, forjadas nas e pelas revoluções burguesas clássicas.

A ideologia da globalização, objetiva e subjetivamente, converteu-se na forma mais avançada de expansão e dominação do capital-imperialismo. Deve-se destacar que o capital não pode prescindir de sujeitos políticos coletivos, capaz de materializar, seja pela coerção social direta e/ou indireta, seus interesses, seja na esfera nacional, seja na esfera internacional. Assim, por um lado, necessita de instituições supranacionais, tais como: G-7; FMI; OMC; Banco Mundial... de tal forma a esvaziar instituições supranacionais, com potencial democrático, como a ONU, como forma de garantir os interesses do capital-imperialismo rentista-financista; e, contraditoriamente, necessita dos Estados nacionais, para administrar e organizar a política-econômica e sociocultural, necessárias a garantia de seus interesses, no complexo sistema de círculos concêntricos que caracteriza a periferia capitalista. Assim, na periferia capitalista, passa a predominar democracias formais esvaziadas, estruturadas na e pela força da espada, caracterizadas como autocracias burguesas institucionalizadas 
(FLORESTAN, 2005). Articulam-se plutocracias e oligarquias rentistas-financistas globais, regionais e locais, que passam a administrar e organizar os círculos concêntricos de dominação, impostos pelo capitalimperialismo.

A ciência e a tecnologia como dominação constituem-se em uma complexa forma de ideologia e passa a ser o principal instrumento legitimador da dominação, seja do ponto de vista objetivo, à medida que a ciência e a tecnologia possibilitam a dinamicidade e expansão do capital, mesmo em um contexto de crise estrutural do capital; seja do ponto de vista subjetivo, à medida que se difunde uma concepção de sociedade do conhecimento e da informação - via Tecnologia da Informação e do Conhecimento (TIC) -, contraditoriamente, estruturada em uma concepção de liberdade programada. Assim, tais processos passam a influenciar a forma e o conteúdo do comportamento, dos hábitos e costumes sociais, criando-se a ilusão de que as chamadas "redes sociais", altamente individualizadas, ideologizadas e alienantes, possam alterar os rumos e a dinâmica da sociedade. Cria-se a ilusão de que o indivíduo, enquanto mônada individual-singular, poderia influenciar e/ou alterar as formações sociais, quando sua forma de ser em-si-mesmada reproduz o comportamento padrão de dominação, inconscientemente.

O processo de reprodução ampliada do capital, em sua lógica e dinâmica, tende a mercantilizar todas as relações sociais. O surgimento e a difusão das chamadas TICs potencializaram o processo de mercantilização do conhecimento, e, consequentemente, do conjunto das relações sociais formativas, formais e informais, a partir das quais se estruturam novos processos de interação social e socialização. As TICs passaram a forjar, de forma integrada, um conjunto de recursos tecnológicos, voltados, única e exclusivamente, para o processo de reprodução ampliada do capital, de tal forma a integrar, de forma reificada, todas as esferas da vida.

A criação e o desenvolvimento de hardwares, softwares e a própria internet, cada vez mais presentes na vida cotidiana, via difusão de uma variedade de softwares aplicativos móveis (App), forjaram um tipo específico de comunicação - pragmático-utilitarista e virtual -, despida de toda e qualquer concepção de mediação, na e a partir da qual se constituem novos tipos de interação social e socialização. Trata-se de tipos particulares de comunicação reificada, na medida em que os aparentes indivíduos operam e são operacionalizados, enquanto programas computacionais. Do ponto de vista objetivo, as TICs integram o processo de reprodução ampliada do capital, submetendo o indivíduo à lógica de reproducão ampliada do capital, em todas as esferas da vida; do ponto de vista subjetivo, forja simulacros dentro de simulacros, criando-se a ilusão de liberdade e igualdade.

A lógica de reprodução ampliada do capital captura a subjetividade dos indivíduos, a partir da operacionalidade e instrumentalização das TICs, visto que a comunicação reificada difunde processos de homogeneização dos comportamentos, hábitos e costumes sociais, de forma inconsciente. Do ponto de vista objetivo, as TICs integram as esferas da produção, circulação e comercialização das mercadorias, aos processos de operacionalização do capital rentista-financista; do ponto de vista subjetivo, captura a subjetividade dos indivíduos, via uso cotidiano das tecnologias de informação e comunicação, subsumidas na forma dos aplicativos móveis, em todas as esferas da vida, visto que sua 
utilização, instrumentalização e operacionalidade, acabam por gerar bancos de dados, que a partir da utilização de algoritmos específicos, armazenam, permanentemente, informações individualizadas dos usuários; e, ao fazê-lo, traça perfis político-econômicos e socioculturais, instrumentalizados política, econômica e culturalmente, pelas corporações que os controlam. Trata-se do surgimento de um novo tipo de indivíduo. Contraditoriamente, um indivíduo programado.

A ideologia da globalização está estruturada no neoliberalismo-flexível, que pode ser definido enquanto determinação objetiva e subjetiva de um novo ciclo de acumulação, em um cenário de crise estrutural do capital e de objetivação plena do capital-imperialismo, no e a partir do qual se constituiu uma plutocracia-oligarquia rentista-financista mundializada. Tais processos encontram-se estruturados nas e pelas chamadas revoluções científico-tecnológicas, na medida em que inseriu transformações profundas, tanto no âmbito da reprodução ampliada do capital, quanto do conjunto das relações sociais. Ora, tais processos implicam em ampliação da produtividade, via espoliação extremada dos trabalhadores, ao mesmo tempo em que constitui setores diversificados e complexos de trabalhadores, dotados de diferentes tipos e níveis de conhecimentos científicos e tecnológicos. A ciência e a tecnologia como dominação realizam-se plenamente, objetiva e subjetivamente, a partir da mundialização das TICs, via padrão de acumulação do capital neoliberal-flexível.

Forjara-se a ilusão de que a produção do conhecimento científico e tecnológico, por si só, seria capaz de produzir um novo tipo de riqueza, denominada conhecimento; e, consequentemente, acumular capital. Todavia, não se trataria de produção de conhecimentos científicos e tecnológicos em-si-mesmados, mas da integração plena dos processos de produção do conhecimento e da tecnologia a esfera de reprodução ampliada do capital, de tal forma que as grandes corporações passaram a controlar e a intervir diretamente nas instituições educacionais, definindo seus currículos, programas, pesquisas... ao mesmo tempo em que difundiam, permanentemente, em todos os cursos, níveis e modalidades de ensino, a ideologia do empreendedorismo. Tratar-se-ia, não somente de instituir e difundir a cultura da especialização e fragmentação permanente das profissões, mas tornar todos os indivíduos, independentemente das profissões, empreendedores; ou seja, vendedores de serviços, produtos e processos administrativo-organizativos, despedidos de toda e qualquer relação éticomoral, que não fosse aquela difundida pela entidade metafisica do capital, denominada mercado: competitividade e lucro.

O capital-imperialismo, por um lado, opera pela via da colonização dos Estados nacionais, apropriando-se de sua estrutura jurídico-política, de suas instituições, de seu orçamento e transformando suas principais atividades, político-econômicas e socioculturais, em negócios altamente rentáveis. Trata-se de um cálculo racional que diminui os riscos do grande capital, na medida em que o Estado passa a ser o fiador dos negócios; e, por outro, constitui mecanismos e instituições produtoras e reprodutoras de uma formação distorcida da subjetividade, a partir das quais naturaliza os indivíduos e os converte em competidores empresariais, via difusão da ideologia do empreendedorismo. 
Se, por um lado, um dos valores mais elevados das revoluções burguesas encontrava-se no marco da criação das condições objetivas e subjetivas de manifestação e desenvolvimento das liberdades individuais, mediante processos agudos e profundos de individuação; por outro, os processos de socialização e interação burgueses, inclusive no âmbito das instituições educacionais, na medida em que se distanciaram do legado do aufklärung, criaram mecanismos inconscientes de reificação dos próprios processos de individuação, de tal forma a homogeneizar e fazer do indivíduo uma mercadoria programada. No âmbito do capitalismo contemporâneo, os processos de individuação são interditados, na medida em que as TICs os absorvem e os homogeneízam, transformando-os em mercadorias programadas, e, consequentemente, em manifestação de liberdade individual aparente ou liberdade programada.

No âmbito dos avanços das TICs, os processos de socialização e interação, foram absorvidos pelas "redes sociais" - formas reificadas de aprendizagens intuitivas -, na e a partir das quais se desenvolveu um elogio inconsciente à imediaticidade, expresso nas manifestações imediatas dos sentidos, bem como na impossibilidade de construção de mediações e reflexões autônomas dos processos de socialização e interação. Trata-se de uma quebra e de uma aceleração do tempo. O tempo fragmentado e acelerado impede toda e qualquer possibilidade de elaboração e recuperação da experiência formativa, restando em seu lugar, feixes de tempo (despidos de luz) e de percepção de si e da realidade: formas reificadas de simulacros dentro de simulacros. O fetichismo da técnica converteuse em ideologia da tecnologia, na medida em que colonizou os processos formativos, de tal forma a bloquear as possibilidades de recuperação da experiência enquanto elaboração do processo formativo. Trata-se do desaparecimento do lampejo de indivíduo livre, esboçado pelo aufkelärung, de tal forma a emergir em seu lugar a mercadoria programada, enquanto expressão da manifestação fenomênica de indivíduos livres. Todavia, nem são indivíduos, nem são livres.

Trata-se de uma quadratura histórica na qual os princípios emancipatórios advindos das revoluções burguesas clássicas, como aqueles estruturados no aufklärung, necessitam ser destruídos, para que o novo ciclo de acumulação do capital se realize, sob a hegemonia neoliberal-flexível, que no âmbito da educação se materializa sob a forma da pedagogia da hegemonia. Assim, o neoliberalismo é uma negação histórica do próprio liberalismo clássico, na medida em que enquanto o último instituiu processos civilizatórios de emancipação política dos indivíduos; o primeiro instituiu processos de desemancipação e de barbárie, destruindo, no limite, uma de suas principais virtudes: as liberdades individuais.

No decorrer do século XIX, o capitalismo se consolidou enquanto modo de produção expansivo e dinâmico, com tendência crescente a mundialização, de tal forma que o conhecimento encontrava-se restrito e limitado à indústria, particularmente, ao controle e domínio da maquinaria. Diferentemente, no decorrer do século XX, o conhecimento expande-se do controle e domínio da maquinaria para os processos de administração e organização dos processos produtivos, nos quais a maquinaria passa a ser subsumida. Tratar-se-ia da constituição de um tipo particular de indústria, fundamentada em cálculos racionais objetivos e programados, em todas as suas esferas; e, portanto, 
a lógica da produção fabril deveria deslocar-se de dentro da fábrica e expandir-se, de tal forma a colonizar o conjunto das relações sociais. Nesse sentido, a administração, organização e controle do processo formativo, passam a ser de fundamental importância para o processo de reprodução ampliada do capital.

A Escola, idealizada e difundida pelos iluministas, passou a ser absorvida de maneira direta e intencional, pela lógica da reprodução ampliada do capital. Tal processo, à medida que se aprofundou, forjara os fundamentos da Escola-empresa, difundida pelo neoliberalismo-flexível. Tratar-se-ia de um fenômeno particular, próprio da crise estrutural do capital e, portanto, do neoliberalismo-flexível, na medida em que todas as formas de organização, administração e estrutura pedagógica escolar, estariam voltadas a reprodução ampliada do capital, de tal forma a romper com toda e qualquer possibilidade emancipatória, mesmo os fundamentos de tipo metafísicos, advindos do aufklärung.

A Escola-empresa caracteriza-se por ser a expressão objetiva e subjetiva dos processos de reestruturação produtiva fabril, de tal forma a implementar um tipo de Currículo Instrumental, flexível e adaptável a dinâmica dos ciclos de acumulação do capital. Assim, o Currículo Instrumental (SILVA, 2019) expressa um tipo particular de sistema produtivo, no e a partir do qual objetiva-se produzir em massa tipos de mercadorias programadas, mediante processos produtivos homogeneizados, ora verticalizados, ora horizontalizados, a depender das particularidades dos Estados nacionais e dos ciclos de acumulação do capital.

O processo produtivo, aparentemente interno à indústria, extrapola a indústria e passa a se impor e a colonizar o conjunto das relações sociais. No âmbito da Escola-empresa, estrutura-se um tipo de trabalho parcelar e fragmentado, no qual, tanto o aluno, quanto o professor, são meros repetidores de ações alienadas e alienantes, posicionando-os enquanto peças de funcionamento da maquinaria, que passaria a programar a repetição e a delimitar, a partir de um cronômetro, o tempo e o ritmo de suas ações. Todavia, diferentemente da lógica interna à indústria, a Escola-empresa não seria capaz de extrair mais-valia, ao menos, de forma direta. Todavia, poderia fazê-lo, mediante integração do processo formativo e de produção do conhecimento ao processo de reprodução ampliada do capital. Tal integração, promovida e enraizada pelas TICs, transformaria, todos os sujeitos envolvidos nos mais diversos processos, em mercadorias programadas, na medida em que operaria pela captura da subjetividade.

De forma embrionária, a Escola-empresa caracteriza-se por ser uma mescla da produção em série fordista com o cronômetro taylorista, instituindo de maneira rígida a separação entre elaboração e execução, como uma espécie de trabalho rotinizado, programado e fechado para a criatividade. Assim, a Escola-empresa encontra sua determinação plena sob a égide do processo produtivo do toyotismo-ohnismo, na medida em que instituiu processos produtivos autocráticoregressivos, no e a partir dos quais a produção de mercadorias programadas caracterizar-se-ia por ser aparentemente variada e heterogênea, na medida em que se encontraria umbilicalmente articulada a um tipo particular de demanda. Tratar-se-ia de um Currículo Instrumental que atendesse a necessidades de produção, circulação e consumo, imediatos, e, aparentemente, individualizadas. Tratar-se-ia da 
constituição de um processo formativo, adaptado a estrutura de um novo tipo de mercado de trabalho, caracterizado pela precariedade, altos níveis de espoliação e informalidade. Diferentemente do Currículo Instrumental de tipo taylorismo-fordismo, que se fundamentava na produção em série e de massa, no Curriculo Instrumental de tipo toyotismo-ohnismo, opera-se pela constituição de equipespolivalentes, que passariam a assumir uma multivariedade de funções, de tal forma a romper com a lógica parcelar do fordismo, que condicionava o trabalhador ao ritmo e ao tempo de uma máquina específica. Assim, o Currículo Instrumental de tipo taylorista-fordista fora subsumido à dinâmica do toyotista-ohnista, como forma de forjar o fenômeno da Escola-empresa.

O novo padrão produtivo de acumulação do capital exigiria flexibilidade, tanto da estrutura do sistema produtivo e da força de trabalho empenhada, quanto do próprio processo de formação da subjetividade. Tratar-se-ia da implementação do princípio just in time na própria estruturação da Matriz Curricular, no e a partir do qual a maximização da produtividade deveria ocorrer em um menor tempo possível. Implementar-se-ia o sistema kanban na Escola-empresa, via Matriz Curricular flexível, parcelar e fragmentada, na medida em que programar-se-ia um conjunto de senhas de comando, como forma de reposição rápida de peças e, ao mesmo tempo, de redução do estoque a necessidades imediatas.

O princípio fordista de constituição de grandes estoques homogêneos fora convertido em um princípio de tipo toyotista-ohista de estoques necessários e heterogêneos a demandas individualizadas e imediatas. O rígido complexo de verticalização fordista-taylorista, fora substituído pela horizontalização do complexo produtivo toyotista-ohista, que passara a produzir o mínimo necessário em suas Escolas-empresas - teoria do foco -, de tal forma a terceirizar a maior parte da produção. Trata-se de um novo processo de reestruturação da Escola-empresa, na qual buscar-se-ia incrementar, sem limites, o trabalho morto corporificado no maquinário técnico-científico, ou seja, em um mercado rotinizado, programado e flexível, a ser expandido e consolidado (o uso das novas tecnologias, tanto nos processos de administração e organização do espaço escolar; quanto no processo formativo, via Educação à Distância). Implementar-se-ia um processo agudo de liofilizạa̧ão organizacional do processo formativo, no qual reduzir-se-ia drasticamente o trabalho vivo e ampliarse-ia o trabalho morto. Trata-se da Escola-empresa enxuta, fragmentada, heterogênea, como forma de atender a demanda do novo ciclo de acumulação do capital, fundamentado na ampliação progressiva do trabalho informal e na obsolescência programada das profissões e atividades laborais.

As TICs, ao integrar diversos processos societais, criam a ilusão de que a produção científica e tecnológica poderiam produzir-se de forma em-si-mesmada, a medida que os processos de produção e difusão do conhecimento, aparentemente, se autonomizassem. A aparente autonomização do conhecimento o converteu em mercadoria, e, portanto, como quaisquer outras mercadorias, passou a circular e a ser comercializado, tanto como mercadoria, quanto como força produtiva do capital.

O desenvolvimento histórico do capitalismo impõem processos inexoráveis de mercantilização do conjunto das relações sociais, inclusive dos processos de produção e difusão da 
ciência e da tecnologia. Todavia, apesar dos processos de mercantilização coincidirem, diferenciamse, no tempo e no espaço. Por um lado, a mercantilização da tecnologia, entendida enquanto atividade prática da ciência, se objetiva com o advento do sistema reificado de patentes. Ou seja, a ideologia das patentes, mistifica e obscurece os processos de produção tecnológica, à medida que naturaliza e individualiza processos de longo prazo de construção do conhecimento que permitiram que determinada tecnologia se materializasse. Assim, toda tecnologia é necessariamente uma atividade social, que interliga eticamente o gênero humano, a partir do conhecimento produzido socialmente, visto que o gênero humano volta-se a processos constitutivos de mecanismos que possam auxiliar os processos de produção da vida social, objetiva e subjetiva. Entretanto, o sistema reificado de patentes a trata como tecnologia individual, advinda de uma genialidade mística, descolada do conjunto das relações humanas e do conjunto do conhecimento produzido pelo gênero. $\mathrm{O}$ sistema reificado de patentes alcança seu apogeu, ao longo do século XX, com a nova dinâmica assumida pelo capitalimperialismo do pós-II Guerra Mundial. Por outro lado, a mercantilização da ciência, devido à natureza e caráter de pesquisa teórica sistemática, ocorre, ao menos de maneira direta, com o processo de avanço e consolidação do neoliberalismo-flexível, via difusão e consolidação das TICs, sobre a principal instituição que a representa: Instituições de Ensino Superior Públicas, particularmente, as Universidades.

O capitalismo do último quartel do século XX estruturou um sistema reificado de patentes pleno, no e a partir do qual as patentes podem ser comercializadas de diferentes formas: a) compra; b) venda; c) aluguel; d) ações em bolsas de valores... pagamento de royalties. A difusão do sistema de patentes constitui o marco de completude do fenômeno da privatização e mercantilização plena do conhecimento produzido socialmente. A própria universidade alterou sua dinâmica administrativoorganizativa, financeira e pedagógica, para se adequar a lógica de reprodução ampliada do capital, de tal forma a homogeneizar os tempos e processos de integralização curricular, tanto dos cursos de graduação, quanto de pós-graduação, independentemente de suas particularidades formativas e de produção de conhecimento científico, ao mesmo tempo em que conduzia processos de proletariazação dos servidores técnico-administrativo e do próprio corpo docente, via automação de processos técnico-administrativos, que de forma direta implicou a diminuição do número de técnicoadministrativo (seja pela extinção da carreira, seja pela terceirização das atividades meios) e a transferência de tais trabalhos ao corpo docente, intensificando-se o tempo, o ritmo e a jornada de trabalho. Tanto os cursos de graduação, quanto de pós-graduação, passaram a ser hierarquizados, a medida que atendessem as regras e metas, internas e externas, de formação e produção de um tipo particular de conhecimento reificado, de tal forma a tratar o conhecimento produzido como uma mercadoria, e, ao fazê-lo, retirar e desconstruir a função social da Universidade: produzir complexos de conhecimentos, práticos e teóricos, voltados ao bem público. Os tempos de formação passaram a ser diminuídos, flexibilizados, fragmentados e acelerados, tanto em nível de graduação, quanto de pós-graduação. Os Programas de Pós-Graduação foram empurrados a lógica da competitividade mercadológica, individual e institucional, de tal forma a serem hierarquizados, tanto os indivíduos 
quanto as instituições, com notas, níveis e metas de produtividades, instituídos via avaliações quantitativas externas, da qual depende o reconhecimento institucional e social, bem como o direcionamento de recursos; e, do ponto de vista subjetivo, a institucionalização de estruturas simbólicas de diferenciação e status social. A lógica interna da Universidade se alterou profundamente, com o avanço do neoliberalismo-flexível, de tal forma a conduzir processos subterrâneos de privatização do conjunto das relações sociais que a estruturam.

\section{Golpe de Estado e redesenho institucional das Instituições Federais de Ensino Superior (IFES), no Brasil do século XXI: mercantilização, retração e elitismo autocrático- obscurantista.}

A Universidade surgiu em 990, em plena Idade Média, com a criação da Universidade de Bolonha, a partir de princípios metafísicos em-si-mesmados que a caracterizava enquanto templo do saber e do conhecimento. Tratar-se-ia de uma instituição cultivada e estruturada pelo princípio e pela concepção de um conhecimento puramente metafísico, descolado das questões fundamentais da mundanidade profana.

O advento do Estado Moderno acabou por redesenhar a concepção e os fundamentos da Universidade, de tal forma a articulá-los de forma direta e intencional aos interesses das classes dominantes, como forma de construir o consenso e a legitimidade do tipo, da forma e do conteúdo da dominação estabelecida; ao mesmo tempo em que vinculava a ciência e a tecnologia ao processo de expansão e dinamicidade do modo de produção capitalista e da sociabilidade burguesa. Assim, a Universidade se tornou uma instituição de Estado, com a função social de formar os quadros diretivos da sociedade burguesa, nas suas mais diversas esferas, ao mesmo tempo em que se tornara guardiã dos princípios constitutivos da sociabilidade burguesa, e, contraditoriamente do patrimônio sociocultural da humanidade. Portanto, seu fundamento repousa em uma contradição fundamental: ao mesmo tempo em que se constituiu enquanto instituição voltada aos interesses das classes dominantes, ao ser responsável por salvaguardar os princípios advindos das revoluções burguesas clássicas, acabou por abrir espaço para que as classes trabalhadoras e demais classes subalternas pudessem reivindicar e ocupar espaço em sua estrutura interna. Tratar-se-ia da gestação de uma Universidade Popular, antípoda à Universidade do Capital, voltada a dialogar diretamente com as necessidades, as opressões e os flagelos impostos pela sociabilidade burguesa a maioria da humanidade. Portanto, tratar-se-ia de uma Universidade, fundamentalmente, civilizatória, com propósito e perspectivas de emancipação humana. Assim, sua função social passaria a ser redefinida de acordo com a correlação de forças presente tanto no interior da Universidade, quanto na vida social. Na medida em que a Universidade se converteu em instituição de Estado e passou a gozar de autonomia, a Sociedade Civil do Mundo do Trabalho passou a influenciar em seus processos, obrigando-a absorver pautas que contrariavam e contrariam os próprios interesses do capital. 
Portanto, á medida que a Universidade se tornou instituição de Estado, exigiu que se forjasse e se constituísse um corpo de funcionalismo especializado, com autonomia relativa, em relação aos interesses imediatos e diretos dos governos (local, regional e central), fossem eles quais fossem, de tal forma que passou a abrir espaço para que a Sociedade Civil do Mundo do Trabalbo pudesse intervir e influenciar em sua dinâmica interna, e, portanto, disputar a concepção e a função social predominante, no interior de uma instituição eminentemente burguesa. O funcionalismo especializado só poderia constituir-se enquanto funcionalismo público, contratado mediante concurso público, estruturado em carreira específica e marcada pela estabilidade. Assim sendo, o funcionalismo público, estável e de carreira, compatível com uma instituição de Estado, fora forjado, não por interesse corporativo - como a agenda do Golpe tenta fazer crer -, mas por interesse público e como, única e exclusiva, forma de garanti-lo e efetivá-lo. Sem um corpo administrativoorganizativo, especializado, permanente e estável, o Estado moderno e, portanto, suas instituições não seriam possíveis. Assim, a própria concepção de república burguesa e democracia liberalrepresentativa moderna, não seriam possíveis.

Foi a partir de tal processo que se consolidou a concepção de Universidade Pública, estruturada na indissociabilidade do tripé ensino-pesquisa-extensão, visto que a produção de pesquisa sistematizada, concentrada e centralizada em determinada instituição, era importante, mas não suficiente para atender aos anseios e a dinâmica das sociedades burguesas. A lógica interna de expansão e dinamicidade do capitalismo, principalmente, com o avanço científico e tecnológico, acabou por pressionar as sociedades burguesas a aumentar os níveis de escolarização, visto que toda política econômica necessita de uma política educacional, para seu desenvolvimento e efetivação. Isso não quer dizer, em absoluto, que a pressão pelo aumento dos níveis de escolarização, em todos os níveis, represente processos igualitários de acesso, permanência e êxito, naquilo que diz respeito à oferta de ensino pelas instituições educacionais. Pelo contrário, a sociedade capitalista se estrutura nos princípios da competitividade, hierarquização e diferenciação social; e, portanto, o acesso - a permanência e o êxito - à instituições educacionais, também se encontram submetidos a tais princípios, de tal forma a estruturar um tipo de sistema educacional marcado pela dualidade estrutural: 1. Formação propedêutica, fundamentada nas ciências e nas artes, para as classes dominantes; e, 2, Formação técnica, pragmático-utilitarista, aligeirada e fragmentada, para as classes trabalhadoras e demais classes subalternas. A dualidade estrutural está presente no conjunto das instituições educacionais, internas aos Estados nacionais, bem como na esfera das relações internacionais, como forma de administrar, organizar e coordenar a divisão internacional do trabalho. Portanto, a definição de tais processos estariam, umbilicalmente, articuladas as necessidades estruturais/conjunturais dos complexos sistemas de dominação de círculos concêntricos, (re)estruturados pelo capitalimperialismo. Tratar-se-ia de uma fratura profunda que se reproduziu e se reproduz, em todos os níveis de ensino; e, perpassa pela contraposição e contradição que atravessa diferentes tipos e formas de binômios, presente, de forma imediata, na relação entre instituições públicas e privadas: 
1. Ensino Básico: a dualidade estrutural impõe-se a partir de um sistema de ensino, no qual as melhores escolas encontram-se no âmbito das instituições privadas e são reservadas as classes dominantes e médias, de tal forma que as instituições públicas, com raríssimas exceções (Institutos Federais de Educação, Ciência e Tecnologia que atendem $2 \%$ dos alunos em idade escolar, e, trabalha com um tipo de formação que integra o ensino médio ao técnico), possuem péssima qualidade e são reservadas as classes trabalhadoras e subalternas;

2. Ensino Superior: a dualidade estrutural impõe-se a partir de um sistema de ensino, no qual as melhores universidades encontram-se nas instituições públicas e são reservadas as classes dominantes e médias, de tal forma que as instituições privadas, com raríssimas exceções (Fundação Getúlio Vargas; PUC; Mackenzie; UNISINOS...), possuem péssima qualidade e são reservadas as classes trabalhadoras e subalternas;

Apesar da contradição primordial, deve-se destacar que a dualidade estrutural também se encontra presente nas relações internas entre as instituições privadas e entre as instituições públicas, tanto naquilo que diz respeito ao Ensino Básico, quanto Superior, visto que as instituições passam a ser hierarquizadas, como forma de atender a nichos específicos do mercado consumidor de conhecimento, formador de um tipo particular de capital humano reificado que ao se constituir enquanto forma de diferenciação social, passa a ocupar status sociais distintos no interior da sociedade. Assim, a tendência mundial à universalização do ensino básico e superior, encontra-se submetida à dualidade estrutural que fundamentam os diferentes tipos de sistemas educacionais, presentes em dados Estados nacionais, forjados a partir de suas particularidades específicas.

A dualidade estrutural do sistema educacional brasileiro, em uma conjuntura de Golpe de Estado e crise das instituições públicas, passa a ser instrumentalizada politicamente, como forma de legitimar uma política de destruição e/ou retração do sistema educacional de ensino básico e superior públicos do país, visto que passaram a apresentar potencial democratizante, durante a contraditória política de conciliação de classes petista. Cria-se uma falsa dicotomia, naquilo que diz respeito ao processo distributivo do orçamento, aparentemente limitado e restrito, argumentando-se que as instituições de ensino superior públicas são caras e sem retorno, em contraposição as instituições de ensino básico, públicas, que são precárias e necessitam de mais orçamento ${ }^{3}$. Forja-se um falso dilema dicotômico, com um fundo de disputa pela distribuição do orçamento, a partir do qual a sociedade teria que escolher em investir em ensino básico ou superior, quando parcela significativa do orçamento é consumida pela estrutura obscura da divida pública ${ }^{4}$, na e a partir da qual o capital rentista-financista garante seus interesses privados.

O debate da distribuição do orçamento restrito emerge como um instrumento político de manipulação e instrumentalização da opinião pública, a partir do qual se projeta e cria a ilusão do servidor público corporativista e privilegiado, em contraposição ao trabalhador informal, precarizado, intermitente, desempregado... e desprovido de direitos, como forma de legitimação dos processos autocrático-regressivos de privatização do serviço público e agravamento dos índices de desigualdade do país. Como fora observado, a República moderna e a própria democracia formal liberalrepresentativa, não seriam possíveis, sem um complexo sistema de instituições de Estados, estruturadas a partir da constituição de um corpo de funcionalismo especializado, estável e permanente, dentre as quais encontra-se a Universidade. 
Deve-se destacar que o Golpe de Estado soft de 2016, de tipo parlamentar-judicial-midiático (SILVA, 2017), tinha e tem como objetivo redesenhar as instituições públicas brasileiras, "pelo alto", de tal forma a alinhá-las e submetê-las aos interesses do capital-imperialismo, particularmente, aos dos Estados Unidos da América. Nesse sentido, o Golpe de Estado forjou um Estado de Exceção que vem se aprofundando progressivamente e caminhando em direção ao fechamento completo do regime no Brasil. No campo da educação, o Governo Provisório de Exceção de Michel Temer (20162018), conduziu uma política Contrarreformista que alterou profundamente a concepção e a estrutura do Ensino Básico no Brasil, via aprovação autocrática da Contrarreforma do Ensino Médio (SILVA, 2018) e da BNCC (SILVA, 2019). As eleições parcialmente interditadas de 2018 acabaram por ungir Jair Bolsonaro (PSL - Aliança pelo Brasi $)^{5}$, presidente da República, de tal forma a legitimar o Golpe de Estado de 2016 e garantir a continuidade da agenda Contrarreformista.

Se no âmbito do Ensino Básico, o Governo Provisório de Exceção de Michel Temer (MDB-PSDB-DEM), tendo à frente do Ministério da Educação a gestão Mendonça Filho/Maria Helena Guimarães de Castro, conduziu, em sua plenitude, a Contrarreforma da Educação Básica; caberia ao Governo de Exceção, comandado por Jair Bolsonaro (Aliança pelo Brasil) ${ }^{6}$, conduzir a Contrarreforma do Ensino Superior. Incialmente, Bolsonaro nomeou, para conduzir o Ministério da Educação (MEC), o obscurantista-olavista Ricardo Vélez $(1943 \text { - ) })^{7}$, demitido pela mais absoluta incompetência e incapacidade de entender um ministério complexo, como o da educação ${ }^{8}$. No mesmo dia em que demitiu Vélez, nomeou o executivo do mercado financeiro, igualmente obscurantista-olavista, Abraham Weintraub (1971 - ) $)^{9}$, que vem conduzindo um conjunto de medidas autocrático-regressivas, como forma de encaminhar, "pelo alto", a Contrarreforma do Ensino Superior, no Brasil. Assumindo um papel de figurante, no Governo de Exceção de Jair Bolsonaro (Aliança pelo Brasil), o político, tenente-coronel aviador da reserva e "astronauta", Marcos Pontes $(1963-)^{10}$, fora nomeado para assumir o "inexistente” Ministério da Ciência, Tecnologia, Inovações e Comunicações (MCTIC), do qual não se ouviu pronunciamento oficial, após intervenção autocrático-regressiva de Jair Bolsonaro, no Instituto Nacional de Pesquisas Espaciais (INPE) ${ }^{11}$, que culminou na demissão de Ricardo Galvão ${ }^{12}$.

No dia 17 de julho de 2019, o então ministro da educação, anunciou, de forma unilateral, sem nenhum diálogo com as IFES - que possuem autonomia didático-cientifica, administrativa e de gestão financeira e patrimonial, portanto, de forma inconstitucional -, o "Programa Universidades e Institutos Empreendedores e Inovadores", sob a denominação eufêmica: Future-se ${ }^{13}$. Doravante, denominar-se-á: "Programa Bolsonarista", de tal forma a definir com clareza e distinção, tanto sua forma, quanto seu conteúdo autocrático-obscurantista: do ponto de vista formal, predomina-se a inconstitucionalidade de toda sua estrutura, já do ponto de vista do conteúdo, predomina os fundamentos da cultura política fascista: anti-intelectual e anticultural, voltado, inteiramente, a mercantilização dos processos institucionais. Seguindo a estratégia autocrática da gestão Mendonça Filho/Maria Helena Guimarães de Castro, a gestão Weintraub, anunciou o "Programa Bolsonarista", submetendo-o a uma suposta "consulta pública", por pouco mais de quarenta dias, como forma de esvaziar o debate público e 
instrumentalizar, de forma despolitizada a "proposta", utilizando-se das corporações que monopolizam os meios de comunicação no Brasil, para legitimar o projeto autocrático-regressivo e utilizar o discurso de que a população estaria sendo consultada.

Deve-se destacar que a "consulta pública” fora organizada por uma Organização Social (OS) - Centro de Gestão e Estudos Estratégicos/CGEE -, sem chamamento público, de tal forma a descumprir vários requisitos do Decreto n $\mathrm{n}^{\circ}$ 9.191, de 01 de novembro de 201714, que “[...] estabelece as normas e as diretrizes para elaboração, redação, alteração, consolidação e encaminhamento de propostas de atos normativos ao Presidente da República pelos Ministros de Estado". Trata-se de normativa emitida pelo Governo Transitório de Exceção de Michel Temer (MDB-PSDB-DEM), como forma de atribuir certa normalidade institucional, em um contexto de Golpe de Estado. A instrumentalização política da "consulta pública" sequer permitia que a minuta do Projeto Lei (PL) fosse apreciada, pelas 59.204 que se dispuseram a fazer o cadastro.

O "Programa Bolsonarista" estrutura-se em 45 artigos e 7 capítulos que alteram, de forma direta, 18 leis; e, tem como objetivo transformar as IFES em Universidade/Instituto-Empresa. Do ponto de vista estrutural, articula-se em três eixos: 1. Gestão, Governança e Empreendedorismo; 2. Pesquisa e Inovação; e, 3. Internacionalização. Todavia, pode-se dizer que o eixo-central, encontra-se no primeiro, no e a partir do qual se estrutura todas as formas de desconstrução institucional da autonomia das IFES e mercantilização das instituições, em todas as suas esferas. Obviamente, que a política autocrático-regressiva, presente no primeiro eixo, possui desdobramentos que alteram profundamente o segundo e terceiro eixos, a curto, médio e longo prazo. Com relação a tais eixos, pode-se citar a política de desconstrução institucional tanto do $\mathrm{CNPq}^{15}$, quanto da Capes ${ }^{16}$, via cortes orçamentários recorrentes e proposta obscura de fusão ${ }^{17}$, de tal forma a comprometer tanto o processo de produção de pesquisa cientifica de base/aplicada, quanto de internacionalização das IFES.

Uma das estratégias políticas do Governo de Exceção de Jair Bolsonaro (Aliança pelo Brasil) tem sido esvaziar os debates políticos relevantes, como forma de deseducar e despolitizar a sociedade. Assim, a propaganda difundida pelo MEC e pelas corporações que monopolizam os meios de comunicação no Brasil, apresentava como objetivo do "Programa Bolsonarista": "A proposta do MEC com o Future-se é aumentar a autonomia administrativa, financeira e de gestão das universidades e institutos federais em todo o país. A adesão ao programa é voluntária." 18 . Tratar-se-ia de um argumento falacioso, na medida em que: "Art.207. As universidades gozam de autonomia didático-científica, administrativa e de gestão financeira e patrimonial, e obedecerão ao princípio da indissociabilidade entre ensino, pesquisa e extensão". (CONSTITUIÇÃO FEDERAL, 2020 ${ }^{19}$. Portanto, tratar-se-ia de uma peça publicitária, com claro e nítido objetivo de enganar a sociedade e forjar um apoio artificial, para justificar uma intervenção unilateral e autocrático-regressiva nas IFES, com a finalidade de redesenhá-las institucionalmente, "pelo alto".

Como forma de driblar a inconstitucionalidade do "Programa Bolsonarista", a gestão autocrático-regressiva Weintraub, estabeleceu que a adesão seria voluntária. Todavia, instituiu que os repasses de recursos públicos estariam condicionados a adesão, pressionando as instituições a 
aderirem de forma coercitiva, sob pena de estrangulamento financeiro. A adesão implicaria, necessariamente, na transferência compulsória da gestão das IFES às Organizações Sociais (OS), como forma de privatizar seu patrimônio e estabelecer uma política de retração institucional. Para tanto, instituía como exigência o estabelecimento de um contrato de gestão, a partir do qual toda a administração-organização, financeira e pedagógica, passaria a ser conduzida por OSs, credenciada pelo MEC, sem chamamento público, como forma de impor as IFES modelos de governança corporativos. Deve-se destacar que não se trata de um Programa, mas de uma política educacional autocrático-regressiva, inconstitucional, antidemocrática e antipopular, que tem por objetivo acabar com a autonomia da IFES, redesenhá-las institucionalmente "pelo alto", como forma de impor um desenho de retração institucional, de tal forma a abrir um processo de liofilização organizacional das IFES, aprofundando-se a elitização do Ensino Superior no Brasil.

$\mathrm{Na}$ primeira versão, o "Programa Bolsonarista" apresentava um instrumento coercitivo, denominado: adesão voluntária, marcado pela inconstitucionalidade, afirmando que caberia aos Conselhos Superiores/Universitários aprovarem a adesão ou a rejeição: por um lado, chantageava as IFES, pela via dos cortes/contingenciamentos orçamentários; por outro, atribuía aos Conselhos Superiores/Universitários a função de autodissolverem-se e, ao fazê-lo, dissolver toda a estrutura administrativo-organizativa das IFES, transferindo-as às OSs. As IFES se constituíram e são instituições de Estado; e, portanto, sua função social está diretamente vinculada aos interesses de Estado. Os Conselhos Superiores/Universitários, por mais que sejam e representem instâncias máximas de discussão-deliberação, não possuem autonomia para se autodissolver e, portanto, dissolver a instituição. Tratar-se-ia de medida autocrática, própria de regimes abertamente ditatoriais.

Após a "consulta pública" e inúmeras críticas, a gestão autocrático-regressiva Weintraub, instituiu a Portaria n ${ }^{\circ} 1.701$, de 30 de setembro de 2019.

Art. $1^{\circ}$ Instituir o Grupo de Especialistas Jurídicos, de natureza técnica, com o objetivo de discutir e consolidar as propostas apresentadas por meio da préconsulta aberta à comunidade sobre o Programa Future-se e elaborar proposição legislativa acerca do referido Programa, a ser encaminhada ao Congresso Nacional. Parágrafo único. A proposta apresentada pelo Grupo de Especialistas terá caráter contributivo e não vinculativo da decisão da autoridade administrativa $(\mathrm{MEC}, 2019)^{20}$.

O chamado Grupo de Especialistas Jurídicos ${ }^{21}$, diante de um conjunto de inconstitucionalidades e fragilidades técnicas do "Programa Bolsonarista", fora forjado, com a finalidade de promover certa ginástica hermenêutica, para atribuir constitucionalidade a um "Programa" inconstitucional, de tal forma a produzir um novo texto - divulgado três meses, após a versão original ${ }^{22}$, de tal forma a circular três versões, sendo que a primeira fora lançado em julho e a segunda e terceira, respectivamente, nos dias 14 e 16 de outubro. Apesar de ter havido alterações formais, não se pode observar diferenças qualitativas, naquilo que diz respeito ao conteúdo, se comparada às versões. Promoveu-se uma alteração de nomenclatura no eixo-central - 1. Gestão, Governança e Empreendedorismo -, denominado, apenas: Empreendedorismo. A inconstitucionalidade explícita da concepção de gestão e governança imposta, se observada os fundamentos da administração pública e do ordenamento 
jurídico-político brasileiro, fora substituída por instrumentos, no mínimo questionáveis e controversos, do ponto de vista de sua constitucionalidade. Todavia, mais sutis, naquilo que diz respeito à primeira versão.

A ginástica hermenêutica do chamado Grupo de Especialistas Jurídicos criou dois instrumentos que a rigor representam o mesmo conteúdo autocrático-regressivo da proposta inicial, sejam eles: 1. Imposição de um Contrato de Desempenho/Gestão, firmado entre o MEC e as IFES que viessem a "optar" pela adesão, aparentemente, estruturado nos termos do $\$ 8$ art. 3723, Constituição Federal/1988 (aparentemente, pois os termos do art. 37 não se aplicam as IFES, na medida em que os termos do art.207 lhes garantem autonomia didático-cientifica, administrativa e de gestão financeira e patrimonial; e, 2. Financiamento do Programa. Os dois instrumentos coercitivos, apontados anteriormente - chantagem explicita de restrição/liberação orçamentária; e, pressão sobre os Conselhos Superiores/Universitários, para se autodissolverem -, permaneceram. Todavia, de forma implícita. Por um lado, os chamados Contratos de Desempenho/Gestão são obscuros, na medida em que não apresentam nenhum estudo de impacto de implementação e/ou critérios mínimos de contratação, avaliação, quantitativa e qualitativa, tampouco, apresenta ordenamento jurídico-político apropriado, capaz de regulamentar tais processos, abrindo-se margem para todos os tipos de irregularidades administrativas, inclusive, de perseguição política sistemática daqueles que se opuserem e/ou simplesmente discordarem de tais processos, denominados pelo ministro de "zebras gordas"24; por outro lado, o Financiamento do "Programa Bolsonarista" institui a criação de dois Fundos: 1. Fundo Patrimonial do Future-se; e, 2. Fundo Soberano do Conhecimento. O primeiro seria constituído pelo MEC e gerido por dois tipos de Organizações: Gestora e Executora - a primeira, com composição e funções desconhecidas; e, a segunda, composta por Organizações Sociais ou Fundações de Apoio, teria a função de administrar os recursos. Trata-se de uma estratégia de desobrigação do Estado, em financiar as IFES, de tal forma que os recursos constitutivos do Fundo Patrimonial adviriam de processos de arrecadação próprias, tais como: doações; locação e/ou venda patrimonial; empréstimos; alienação de bens; prestação de serviços; pagamento de matriculas e mensalidades de pós-graduação lato senso; venda de direitos autorais e/ou patentes... dentre outras atividades passiveis de comercialização. Os recursos próprios das IFES passariam a compor o Fundo Patrimonial, sem ingresso na Conta Única do Tesouro Nacional, de tal forma que até mesmo os recursos próprios submeter-se-iam as diretrizes da $\mathrm{EC} \mathrm{n}^{\circ}$ 95/2016. O segundo - Fundo Soberano do Conhecimento - de natureza privada, seria constituído, estruturado, administrado e gerido por uma instituição financeira, sem chamamento público, de tal forma a ser regido pelas regras da Comissão de Valores Mobiliários (CVM) e estruturado a partir de ações a serem comercializadas na Bolsa de Valores. A composição do chamado Fundo Soberano do Conhecimento não é clara, apenas diz que a União participaria como cotista. O "Programa Bolsonarista", tampouco, o MEC, não diz como se dará o financiamento das IFES que não aderirem, como forma de mantê-las sob pressão; por outro lado, afirma que o acesso aos Fundos estaria condicionado aos termos de adesão, sem nenhum tipo de contrapartida. Assim, os Fundos seriam acessados de acordo com o cumprimento do obscuro Contrato de Desempenho/Gestão. Como forma de atribuir alguma 
legitimidade a processos autocrático-regressivos, desde seu nascedouro, o governo encaminhou nova "consulta pública"25, aberta em 03 de janeiro de 2020. Deve-se destacar que as diferentes versões do "Programa Bolsonarista" não dialogam com os problemas estruturais da IFES, apontados pelos pesquisadores da área, tampouco, com Documentos Institucionais importantes, como o Plano Nacional de Educação (PNE) ${ }^{26}$.

Uma das questões centrais do debate acerca das IFES gira em torno da sustentabilidade financeira. Os críticos das IFES, ao menos, desde os anos de 1990, apontam que as IFES são insustentáveis financeiramente, por serem arcaicas e corporativistas, como forma de atacar a concepção institucional, estruturada como instituição de Estado. Fundamentalmente, a questão da sustentabilidade financeira estrutura-se na relação entre financiamento público e captação de recursos próprios (recursos oriundos, especifica e principalmente, de: i. projetos de pesquisa e extensão; ii. prestação de serviços; iii. projetos de inovação ou de incubação de empresas; iv. concessão de áreas; v. taxas de registro de diplomas; vi. comercialização de livros; vii. acordos; viii. parcerias; ix. cooperaçoes; e, x. convênios). Nesse sentido, ao longo dos últimos 25 anos, particularmente, a partir dos Governos de Fernando Henrique Cardoso (1995-2002), de forma extremada; mas, também de Luís Inácio "Lula" da Silva (2003-2010) e Dilma Rousseff (2011-2016), de forma moderada; avançou uma agenda privatizante indireta, no âmbito das IFES. Assim, forjou-se uma legislação e um conjunto de instrumentos legais e regulatórios, como forma de viabilizar e estimular a captação de recursos próprios - que ingressa à lei orçamentária -, bem como a institucionalização das chamadas Fundaçoes de Apoio ${ }^{27}$ e dos Núcleos de Inovação Tecnológica (NIT). O que diferenciaria os governos anteriores do Governo de Exceção de Jair Bolsonaro (Aliança pelo Brasi) seria, exatamente, o respeito aos ritos e procedimentos institucionais vigentes, características típicas dos governos de conciliação de classes, (tanto dos governos de centro-direita, como o caso dos governos do Partido da Social Democracia Brasileira/PSDB; quanto dos governos de centroesquerda, como o caso dos governos do Partido dos Trabalhadores/PT).

Deve-se destacar que o germe do "Programa Bolsonarista", encontra-se presente na Lei ${ }^{\circ}$ 13.243, de 11 de janeiro de 201628, a partir da qual se estabeleceu no Brasil o novo Marco Legal da Ciência, Tecnologia e Inovação. Nesses termos, a lei em questão, representou o aprofundamento do avanço da mercantilização do Ensino Superior no país, direta e indiretamente. Tal processo, iniciado nos governos de FHC, permaneceram em curso, durante os governos de Lula e Dilma, como pode ser observado, a partir do conteúdo presente, tanto na Lei no 10.973, de 02 de dezembro de 200429, bem como no conteúdo da Lei $\mathrm{n}^{\circ} 11.079$, de 30 de dezembro de 200430, quanto na Emenda Constitucional $\mathrm{n}^{\circ} 85$, de 26 de fevereiro de 201531. Os governos petistas (2003-2016), via política de conciliação de classes, adotaram uma política educacional de preservação relativa da autonomia das IFES, de tal forma a forjar uma legislação e um conjunto de instrumentos legais e regulatórios, como forma de viabilizar e estimular a captação de recursos próprios (que no modelo atual é suplementar) e atender aos interesses do mercado; ao mesmo tempo, preservava resíduos dos fundamentos do artigo 207 da Constituição Federal. 
Deve-se destacar que os instrumentos legais e regulatórios, instituídos pelos governos petistas (2003-2016), somado ao Decreto $\mathrm{n}^{\circ}$ 9.283, de 07 de fevereiro de 201832, emitido pelo Governo Transitório de Exceção de Michel Temer (MDB-PSDB-DEM), possibilitava: 1. Ampliação das atribuições dos Núcleos de Inovação Tecnologica (NIT), podendo esses realizar a captação, a gestão e a aplicação das receitas próprias; 2. Incubação de empresas nas Instituições de Ciência e Tecnologia (ICT); 3. Utilizaçãao e compartilhamento de laboratórios, equipamentos e instalações com outras ICT e com empresas; 4. Licenciamento de patentes e a transferência de tecnologias desenvolvidas pelas ICT; e 5. Participação dos pesquisadores das ICT nas receitas geradas, entre outras possibilidades, ações possíveis desde que estabelecidas pela política institucional de inovação criada pelas IFES. Portanto, o "Programa Bolsonarista" não pode ser entendido como um raio que atravessa céu azul, mas como uma política-econômica do capital, imposta via neoliberalismo-flexível, desde os anos de 1990. Todavia, o cenário de Golpe de Estado de 2016 e a abertura de um Estado de Exceşão, criou um cenário de instabilidade e insegurança jurídica que favoreceram a imposição autocrático-regressiva da agenda do capital para as IFES, fora e por cima do ordenamento jurídico-político vigente, bem como da legitimidade social.

Importante salientar que as IFES, como instituições de Estado que são, compõem a estrutura do MEC, de tal forma que o planejamento de seu orçamento é deliberado de acordo com os instrumentos legais, definidos e delimitados pelo Governo Federal. Assim, o orçamento das IFES é composto de recursos orçamentários oriundos do MEC - definidos, a partir da Matriz para Recursos de Outros Custeios e Capital (Matriz OCC) -, e de receitas próprias. Portanto, todos os gastos das IFES são planejados, organizados e coordenados, a partir de instrumentos regulatórios definidos pelo Governo Federal. Não se trata de uma instituição despida de instrumentos de governança que gasta irresponsavelmente seus recursos, como o Governo de Exceção de Jair Bolsonaro (Aliança pelo Brasi) tenta difundir. Deve-se destacar que as IFES possuem um complexo sistema de gestão e governança, estruturado em eleições diretas, para ocupação dos cargos diretivos, regulamentada por Conselhos Universitários/Superiores, com o objetivo de fiscalizar, discutir e deliberar sobre as questões fundamentais da instituição. Assim, as IFES possuem: a) Plano de Desenvolvimento Institucional (PDI), reestruturado pela comunidade acadêmica, a cada cinco anos; b) Estatuto; c) Regimento Geral; e, d) Auditorias Internas e Externas (órgão de controle: AGU/CGU/TCU), como forma de constituir uma gestão fundamentada nos princípios da transparência e publicidade, bem como, atender a todos os princípios estruturantes da administração pública. Sobre o orçamento das IFES, bem como do sistema educacional público brasileiro, a Constituição de $1988^{33}$ definiu:

Art. 211. A União, os Estados, o Distrito Federal e os Municípios organizarão em regime de colaboração seus sistemas de ensino. $\int 1^{\circ}$ A União organizará o sistema federal de ensino e o dos Territórios, financiará as instituições de ensino públicas federais e exercerá, em matéria educacional, função redistributiva e supletiva, de forma a garantir equalização de oportunidades educacionais e padrão mínimo de qualidade do ensino mediante assistência técnica e financeira aos Estados, ao Distrito Federal e aos Municípios. $\ 2^{\circ}$ Os Municípios atuarão prioritariamente no ensino fundamental e na educação infantil. $\int 3^{\circ}$ Os Estados e o Distrito Federal atuarão prioritariamente no ensino fundamental e médio. $\int 4^{\circ} \mathrm{Na}$ 
organização de seus sistemas de ensino, a União, os Estados, o Distrito Federal e os Municípios definirão formas de colaboração, de modo a assegurar a universalização do ensino obrigatório. $\int 5^{\circ} \mathrm{A}$ educação básica pública atenderá prioritariamente ao ensino regular.

Art. 212. A União aplicará, anualmente, nunca menos de dezoito, e os Estados, o Distrito Federal e os Municípios vinte e cinco por cento, no mínimo, da receita resultante de impostos, compreendida a proveniente de transferências, na manutenção e desenvolvimento do ensino. $\int 1^{\circ} \mathrm{A}$ parcela da arrecadação de impostos transferida pela União aos Estados, ao Distrito Federal e aos Municípios, ou pelos Estados aos respectivos Municípios, não é considerada, para efeito do cálculo previsto neste artigo, receita do governo que a transferir. $\int 2^{\circ}$ Para efeito do cumprimento do disposto no caput deste artigo, serão considerados os sistemas de ensino federal, estadual e municipal e os recursos aplicados na forma do art. 213. \ $3^{\circ} \mathrm{A}$ distribuição dos recursos públicos assegurará prioridade ao atendimento das necessidades do ensino obrigatório, no que se refere a universalização, garantia de padrão de qualidade e equidade, nos termos do plano nacional de educação. $\int 4^{\circ}$ Os programas suplementares de alimentação e assistência à saúde previstos no art. 208, VII, serão financiados com recursos provenientes de contribuições sociais e outros recursos orçamentários. $\int 5^{\circ} \mathrm{A}$ educação básica pública terá como fonte adicional de financiamento a contribuição social do salário-educação, recolhida pelas empresas na forma da lei. $\int 6^{\circ}$ As cotas estaduais e municipais da arrecadação da contribuição social do salário-educação serão distribuídas proporcionalmente ao número de alunos matriculados na educação básica nas respectivas redes públicas de ensino.

A Lei $n^{\circ}$ 9.394, de 20 de dezembro de 1996 (LDBEN/1996), reafirmou os fundamentos dos artigos 211 e 212 da Constituição Federal, de tal forma a definir “Art. 55. Caberá à União assegurar, anualmente, em seu Orçamento Geral, recursos suficientes para manutenção e desenvolvimento das instituições de educação superior por ela mantidas"34. Assim sendo, o primeiro eixo apontado pelo "Programa Bolsonarista", em suas três versões, visa deseducar e despolitizar a sociedade, difundindo um conjunto de informações enganosas e fraudulentas, acerca do ordenamento jurídico-político do país, bem como do funcionamento, administração e organização das IFES. Tal estratégia fora utilizada, por Jair Bolsonaro (Aliança pelo Brasi), durante a campanha presidencial de 2018 e permaneceu como concepção e estratégia de governança.

O debate acerca da sustentabilidade financeira das IFES tem sido utilizado como cortina de fumaça, para viabilizar a mercantilização do sistema educacional superior no Brasil, como forma de privatizar as IFES, de maneira direta e indireta. Importante salientar que as IFES possuem funções sociais fundamentais para o desenvolvimento político-econômico e sociocultural do país, tais como: 1. Formação e Qualificação Profissional: historicamente, superior ao modelo privado; 2. Fomentar o desenvolvimento econômico, social e cultural, como forma de interiorizar a ciência e a tecnologia, tornando-se um instrumento de combate às desigualdades regionais; 3. Repositório de Conhecimentos Científicos, Tecnológicos e Culturais da Sociedade, portanto, responsável por salvaguardar o patrimônio intangivel produz̨ido social e culturalmente; 4. Produção de Ciência e Tecnologia, a partir do diálogo com os arranjos produtivos e socioculturais, local e regional, como prevê a Lei de criação dos Institutos Federais ${ }^{35}$, portanto, estruturados nos princípios da verticalização e territorialidade.

Destarte, para além da relação pragmático-utilitarista de custo-benefício de curto prazo, as IFES possuem papel civilizatório e emancipatório imensuráveis, mesmo se observada a relação pragmático-utilitarista de custo-benefício, a médio e longo prazo. Tais funções sociais só podem ser 
efetivadas pelas IFES, via financiamento público, laicidade, gratuidade, universalidade e o caráter democratizante de manter-se socialmente referenciada, visto que as Intuições de Ensino Superior Privadas, assim como toda empresa, administra, organiza e gere suas atividades, com uma única finalidade: obter e maximizar lucros. Trata-se de finalidade incompatível com as funções sociais primígenas das IFES, que só podem ser efetivadas por instituições de Estado. Portanto, o debate fundamental não é o de sustentabilidade financeira, mas de modelo e concepção de instituição. $O$ "Programa Bolsonarista" tem ciência da questão; e, objetiva alterar o modelo e a concepção de instituição "pelo alto", como parte de sua estratégia política: por um lado, visa atender aos interesses imediatos do mercado; e, por outro, busca criar as condições objetivas e subjetivas para o fechamento do regime e governar a partir de uma ditadura.

O "Programa Bolsonarista" busca aplicar a agenda neoliberal-flexível extremada, imposta pelo capital, desde o Golpe de Estado de 2016, utilizando-se dos dispositivos da Emenda Constitucional $\mathrm{n}^{\circ}$ 95, de 15 de dezembro de 201636, bem como de reduções orçamentárias, bloqueios e contingenciamentos ${ }^{37}$ arbitrários, para redefinir as instituições políticas brasileiras "pelo alto", dentre as quais, as IFES. Assim, o "Programa Bolsonarista" dialoga diretamente com a agenda neoliberalflexível extremada estrutural, visto que recoloca na ordem do dia o processo de implementação de Organizações Sociais (OSs), forjadas nos e pelos governos de FHC, a partir da aprovação da Lei n. 9.637, de 15 de maio de $1998^{38}$, como forma de transferir a gestão das instituições públicas para o setor privado; ao mesmo tempo, em que dialoga com a agenda neoliberal-flexível extremada conjuntural, visto que aprofunda o processo de privatização das IFES, via dispositivos da EC $\mathrm{n}^{\circ}$ 95/2016, como forma de remodelar a própria concepção de gestão de OSs, que passaram a contar com os dispositivos e instrumentos da Lei $\mathrm{n}^{\mathrm{o}}$ 13.800, de 04 de janeiro de 201939, a partir da qual a iniciativa privada poderá dispor, direta e/ou indiretamente, do patrimônio público:

Art. 1 -Esta Lei dispõe sobre a constituição de fundos patrimoniais com o objetivo de arrecadar, gerir e destinar doações de pessoas físicas e jurídicas privadas para programas, projetos e demais finalidades de interesse público. Parágrafo único. Os fundos patrimoniais constituídos nos termos desta Lei poderão apoiar instituições relacionadas à educação, à ciência, à tecnologia, à pesquisa e à inovação, à cultura, à saúde, ao meio ambiente, à assistência social, ao desporto, à segurança pública, aos direitos humanos e a demais finalidades de interesse público.

Deve-se destacar que a questão fundamental do "Programa Bolsonarista", encontra-se na concepção de modelo institucional; e, em nenhum momento, discute de forma objetiva a questão da sustentabilidade financeira, tampouco, perpassa sobre os problemas quantitativos e qualitativos das IFES. Do ponto de vista qualitativo, pode-se observar a predominância de quatro grandes modelos de instituições de ensino superior no país: 1. Instituiçoees Públicas de Ensino Superior (Federais e Estaduais); 2. Instituições de Ensino Superior Confessionais; 3. Instituições de Ensino Superior Comunitárias; e, 4. Instituições de Ensino Superior Particulares: fundamentadas em empreendimentos privados, estruturada na e pela lógica empresarial-corporativa. Dos quatro modelos existentes, o único modelo exitoso, medido quantitativamente pelo Índice Geral de Cursos (ICG)º é o das Instituições Públicas de Ensino Superior 
( Federal e Estadual), ocupando no ranking nacional de 2018, as vinte quatro primeiras posições, sendo que a vigésima quinta é ocupada por uma Instituição de Ensino Superior Confessional: a Pontifícia Universidade Católica (PUC). O modelo de Instituição de Ensino Superior Privado, fundamentado na lógica empresarial-corporativa ocupa as piores posições do ranking. No âmbito internacional, não é diferente. A Times Higher Education ${ }^{41}$ publicou em 2018 o ranking internacional das melhores universidades do mundo: trinta e seis universidades brasileiras entraram ranking internacional, dentre as quais, trinta e duas eram públicas (vinte e cinco federais e sete estaduais). Apenas quatro privadas figuraram no ranking, das quais três faziam parte do sistema PUC e uma da UNISINOS. Portanto, do modelo de Instituições de Ensino Superior Confessionais. O modelo defendido no e pelo "Programa Bolsonarista" - Instituições de Ensino Superior Particulares: fundamentadas em empreendimentos privados, estruturada na e pela lógica empresarial-corporativa -, sequer consegue alcançar índices aceitáveis, em avaliações de larga escala, puramente quantitativas.

\section{Future-se S.A.: a liofilização organizacional das IFES.}

Durante os governos FHC (1995-2002), fora forjado a chamada Reforma Administrativa42, denominada politicamente de "Reforma Bresser"43, que previa a reforma administrativa do Estado brasileiro, a partir da aplicação da agenda neoliberal-flexível extremada, todavia, preservando-se certo nível de institucionalidade, bem como o ordenamento jurídico-político do país. Os governos de conciliação de classes petistas (2003-2016) adotaram uma política neoliberal-flexível moderada e tentaram conduzir a reforma administrativa do Estado, iniciada pelos governos FHC, de tal forma a preservar regulamentações e garantias mínimas. Com o Golpe de Estado soft de 2016, a agenda do capital, neoliberal-flexível extremada, retomou a pauta extremada dos anos de 1990. Em um cenário de Golpe de Estado e ascensão de um governo de extrema-direita, a agenda passou a ser encaminhada de forma autocrático-regressiva, visto que não há segurança jurídica capaz de impor os dispositivos legais existentes, como forma de normatizar os processos decisórios.

O "Programa Bolsonarista" articula-se a partir de um substantivo masculino - futuro - tornado verbo. Uma peça publicitária autocrático-regressiva, que forja um discurso, aparentemente, modernizador, com fundamentos regressivos, que no âmbito da política educacional desconstrói a concepção de IFES, fundamentada em instituições de Estado, e as transferem para a iniciativa privada, de forma direta e/ou indireta; ao mesmo tempo, os resquícios de instituições públicas existentes, passam a estar submetidas aos sabores/dissabores de governos locais, regionais e central. Assim, articula-se e fundamenta-se a partir de dois movimentos que se complementam: 1. Políticoeconômico, visto que seus objetivos estão alinhados a agenda neoliberal-flexível extremada do Golpe de Estado soft de 2016; e, 2. Sociocultural, visto que se vincula e estrutura-se, a partir de uma agenda político-cultural autocrático-regressiva de extrema-direita, com claro objetivo de intervir direta e unilateralmente nas instituições públicas de ensino, com a finalidade de instrumentalizá-las e tornálas, única e exclusivamente, aparelhos ideológicos do Estado (ALTHUSSER, 1987). Althusser, como é 
próprio do marxismo estruturalista francês, forjou um conceito mecânico-instrumental, como tentativa de constituição de certo nível de entendimento acerca do sistema educacional burguês. Todavia, o conceito, pelos limites metodológicos, não fora capaz de abarcar e traduzir sua complexidade, visto que o sistema educacional burguês forjou estruturas, fundamentos e princípios emancipatórios e civilizatórios que fogem a seu controle. Utilizar-se-á o conceito de aparelho ideológico de Estado, exatamente por entendê-lo, como expressão de uma concepção mecânico-instrumental, e puramente ideológica do sistema educacional.

Os ideólogos da extrema-direita forjaram e articularam um discurso autocrático-regressivo anti-intelectualidade, anti-cientificidade e anti-cultural, como é próprio da cultura política fascista. Assim, ao longo dos últimos anos, disseminaram-se pelo país um complexo sistema de aparelhos privados de hegemonia, que passaram a forjar e difundir projetos, tais como: Escola sem Partido e Escolas cívico-militares; bem como, concepções pseudocientíficas e, puramente, ideológicas, tais como a de marxismo cultural44, das quais a maior representação individual encontra-se na figura do astrólogoobscurantista, Olavo de Carvalho (1947 - ), todavia, seu fundamento encontra-se nos aparelhos privados de hegemonia. A partir de tais projetos e instrumentos discursivos, passaram a difundir concepções anticientíficas, como se cientificas fossem, tais como: i. criacionismo; ii. terraplanismo; iii. antivacinas; iv. antissistema; v. antipolítica; vi. militarismo da vida social; vii. Estado religioso, fundamentado no neopentecostalismo; viii. escola tecnicista; ix. anticomunismo... um amontoado de crenças autocrático-regressivas que passaram a fazer parte do imaginário cotidiano da sociedade brasileira e a fundamentar e estruturar ideologicamente uma determinada concepção de sociedade.

O "Programa Bolsonarista" trás consigo todos os elementos em questão, na medida em que busca deslegitimar as IFES, a partir da difusão de um conjunto de aleivosias sobre a concepção, administração, organização, coordenação e funcionamento das instituições, (des)qualificada pelo ministro como "plantadoras de maconha"45. O Golpe de Estado de 2016 (SILVA, 2017) e seu sustentáculo ideológico - a cultura política autocrático-regressiva da Operação Lava Jato - criaram as condições, objetivas e subjetivas, para que tal concepção se difundisse, articulasse, aglutinasse e ampliasse o número de adeptos. O primeiro impacto da cultura política autocrático-regressiva da Operação Lava Jato sobre as IFES, encontra-se no trágico suicídio do reitor da Universidade Federal de Santa Catarina (UFSC), em 02 de outubro de 201746. Em dezembro do mesmo ano, reitor e vice-reitora da UFMG ${ }^{47}$, seriam conduzidos coercitivamente, pela Polícia Federal. Tratar-se-ia de difundir o discurso ideológico de que todas as instituições políticas brasileiras, inclusive as IFES, seriam corruptas; e, somente, o Ministério Público e a Polícia Federal, ungidos por Deus, trariam a pureza para tais instituições. A partir de tal intervenção casuísta, fora do processo legal e despido de qualquer fundamento jurídico - do qual o maior representante individual é o atual Ministro da Justiça e Segurança Pública (MJSP), Sérgio Fernando Moro $(1972-)^{48}$-, difundiu-se a concepção de que as IFES seriam uma "balburdia"49, convertida em instrumentos políticos de privilegiados, ligados a partidos de esquerda, responsáveis por disseminar o chamado marxismo cultural. 
Do ponto de vista jurídico, o "Programa Bolsonarista" está fora do marco regulatório da própria Lei das OSs - citada anteriormente -, bem como da Lei de Acesso a Informaçãa $0^{50}$. Deve-se destacar que a Lei das $O S s$, questionada, pela sua inconstitucionalidade, desde 1998, só obteve decisão do Supremo Tribunal Federal, em 2015, com o julgamento da Ação Direta de Inconstitucionalidade $A D I / 192351$, já sob Estado de Exceção, decidiu pela constitucionalidade da Lei, regulamentada pelo Governo de Transição de Exceção de Michel Temer, a partir da emissão do Decreto no 9.283, de 07 de fevereiro de 2018. A concepção do "Programa Bolsonarista" é inconstitucional e fere um conjunto de leis que regulamentam a administração pública, abrindo um cenário de incertezas e insegurança jurídica, naquilo que diz respeito à gestão das IFES.

Além dos processos de privatização direta, o "Programa Bolsonarista" prevê processos de privatização indireta das IFES, tais como: 1. A proposta de alteração da LDBEN/1996, naquilo que diz respeito ao reconhecimento de diplomas estrangeiros, por parte de Instituições Privadas, como forma de alavancar o mercado de $\mathrm{EaD}$, nacional e internacional, despido de quaisquer regras e regulamentações mínimas, de tal forma a abrir um mercado concorrencial na área, inclusive para as instituições educacionais de outros países; e, 2. O dispositivo presente no art.15, que prevê a institucionalização de naming rights ou preşo de mercado da imagem da IFES, que passaria alugar e/ou vender a imagem/espaços da instituição, a uma empresa e/ou produto, em troca de patrocínio. Tratar-se-ia de comercializar a credibilidade das IFES, a partir de um processo de aluguel e/ou venda de uma marca institucional, de tal forma a comprometer o pluralismo acadêmico, científico e cultural, que as caracteriza, como forma de desconstruir a indissociabilidade entre ensino-pesquisa-extensão, fragmentando e submetendo tais processos ao lobby corporativo-empresarial. Alinhado a institucionalização de naming rights, observa-se um processo de intervenção e definição didáticopedagógico, como prevê o art. 16. "Admite-se a criação de Sociedade de Propósito Específico - SPE, por departamento, nas IFES, garantindo-se percentual do retorno do lucro auferido para a IFES, nos termos do regulamento". Deve-se destacar que o processo constitutivo de toda e quaisquer pesquisas, sejam elas básicas e/ou aplicadas, exigem a aplicação de recursos a curto, médio e longo prazo. Portanto, exige a montagem/formação de equipes e de processos administrativo-organizativos, coordenação e execução, que levam tempo e, portanto, não podem estar submetidas ao pragmatismo e utilitarismo dos mercados, sob pena de sua completa desarticulação e desaparição. Assim, o "Programa Bolsonarista" destruiria, em um curtíssimo prazo, as instituições que são responsáveis por mais de $90 \%$ das pesquisas produzidas no país ${ }^{52}$, de tal forma a aprofundar sua dependência cientifico-tecnológica, em relação ao capital-imperialismo.

\section{Considerações Provisórias.}

O "Programa Bolsonarista" pode ser definido como: a síntese de um conjunto de processos autocrático-regressivos de ataques difusos as IFES, com o objetivo de redesenhá-las institucionalmente "pelo alto". Não por acaso, a intervenção estruturante encontra-se no primeiro eixo: 
Gestão, Governança e Empreendedorismo. Já no Governo Transitório de Exceção de Michel Temer (MDBPSDB-DEM), a agenda do Golpe apontava para a necessidade de intervenção nas IFES, principalmente, naquilo que diz respeito ao seu orçamento ${ }^{53}$ e a sua gestão ${ }^{54}$ - apesar de eleitos, pelo voto direto da comunidade acadêmica, os reitores são submetidos à apreciação do Executivo, a partir de apresentação de lista tríplice. Os cortes ${ }^{55}$, contingenciamentos ${ }^{56}$ e intervenções ${ }^{57}$, se intensificaram no Governo de Exceção de Jair Bolsonaro (Aliança pelo Brasil), principalmente, a partir da nomeação de Weintraub para o Ministério da Educação. As intervenções ${ }^{58}$ nas IFES se aprofundam, na medida em que o Estado de Exceção se aprofunda.

O "Programa Bolsonarista" é, por um lado, um sistema complexo de cooptação de quadros dirigentes e intelectuais das IFES; por outro, e, de forma complementar, é um sistema de privatização de seus processos administrativo-organizativos, financeiro e didático-pedagógico. Portanto, trabalha com a intersecção de tais movimentos. A medida que intervém nas IFES, sinaliza, para setores da direita e extrema-direita (visto que as IFES, devido a sua função social, são e devem ser pluralistas, possuem em sua composição interna grupos sociais de direita e extrema-direita), que as intervenções poderiam beneficiá-los, direta e/ou indiretamente, seja alçando ao poder grupos que jamais seriam eleitos - a partir de nomeações e mandatos biônicos -, seja acenando para possibilidades de negócios potenciais, a partir da instrumentalização de sua gestão, orçamento e patrimônio, visto que prevê a instituição de um modelo de administração universitária, mediante celebração de Contratos de Desempenho/Gestão com Organizações Sociais (OS), dispensados de processos licitatórios e chamamentos públicos. Deve-se destacar que a gestão, o orçamento e o patrimônio das IFES, envolvem quantias milionárias; e, o "Programa Bolsonarista" prevê a condução de celebração de contratos de gestão pela adoção de procedimentos privados, pessoais e pautados em critérios subjetivos - não por acaso ataca a própria concepção de contratação de servidores públicos, via concurso, afirmando que "os concursos públicos selecionam somente pessoas de esquerda" ${ }^{\prime \prime}$. Os dois movimentos se completam e se retroalimentam.

A gestão histriônica de Weintraub, aparentemente, desprovida de cálculo racional, fundamenta-se na pequena politica e articula instrumentos autocrático-regressivos de cooptação, via intervenção direta e indireta nas IFES ${ }^{60}$. Assim, as IFES deveriam reunir seus Conselhos Superiores/Universitários, para rejeitar, em sua integralidade o "Programa Bolsonarista", de tal forma a afirmar a autonomia didático-cientifica, administrativa e de gestão financeira e patrimonial, fundamentados no principio da indissociabilidade entre ensino, pesquisa e extensão - constituída em um processo histórico de luta de classes favorável à classe trabalhadora e demais classes subalternas -; sem a ilusão de que seria possível amenizar o programa e negociar processos, visto que se trata de um enfrentamento civilizatório e de correlação de forças desfavorável. Tal postura política isolaria os grupos de direita e extrema-direita, presentes no interior das IFES, que as veem como meras prestadoras de serviços e que poderiam, portanto, passar a iniciativa privada, inclusive, submetida a empresas criadas e articuladas por tais grupos; ao mesmo tempo, ergueria uma trincheira de resistência político-cultural, em favor dos processos civilizatórios e democratizantes, tanto das instituições, quanto da vida social. 
As IFES, entidades estudantis, sindicatos, partidos e movimentos sociais, diretamente vinculados à defesa da educação pública, gratuita, universal, laica e socialmente referenciada, não devem cometer os mesmo equívocos que cometeram ao longo do ciclo de derrotas (2013-2018), imposto, pela agenda do Golpe, à classe trabalbadora e demais classes subalternas; e, que se reproduziram nas mobilizações dos chamados $15 M^{61}$ e $30 M^{62}$ - reproduziram a concepção e a lógica do movimento dos indignados espanhóis ${ }^{63}$, marcado pela espontaneidade, fragmentação, negação e ausência da política e de projeto político de curto, médio e longo prazo, como forma de se opor a agenda neoliberalflexível extremada. Na prática, tais movimentos serviram para esvaziar a construção e a pauta da Greve Geral de 14 de junho ${ }^{64}$, movimento que poderia unificar a agenda e a pauta da classe trabalhadora e demais classes subalternas, como forma de alterar a correlação de forças e impedir o avanço do capital sobre o trabalho no Brasil - sejam eles: 1. O não entendimento do Golpe de Estado soft de 2016, como processo autocrático-regressivo de imposição de uma agenda neoliberal-flexível extremada, via Estado de Exceção, como forma de ressubordinação do Brasil ao capital-imperialismo e da classe trabalhadora e demais classes subalternas a nova dinâmica de acumulação do capital; 2. Separação da política educacional da política econômica imposta pela agenda do Golpe; 3. Aposta, irrestrita e incondicional, em uma institucionalidade politicamente comprometida com a agenda do Golpe, e, portanto, marcada pela insegurança jurídica; 4. Protagonismo artificial de indivíduos/entidades, de tal forma a bloquear as possibilidades de construção de uma Frente Única, capaz de resistir e derrotar a agenda do Golpe na sua integralidade; e, 5. Incapacidade de construir a Greve Geral, como instrumento de articulação das pautas e categorias, de tal forma a sair das questões econômico-corporativas e da pequena política e transitar para a construção e consolidação de uma alternativa política classista, necessariamente, anticapitalista, anti-imperialista e estruturada no Poder Popular, ou seja, transitar para o campo da grande política. Sem esse entendimento, possivelmente, estar-se-á diante da expansão do ciclo de derrotas conjunturais, aberto em 2013, com possibilidades de abertura de um ciclo de derrotas estruturais e, portanto, históricas, que implicaria no fechamento completo do regime e, portanto, de todas as instituições com potenciais democratizantes - como as IFES -; chegando, inclusive, a extinção das organizaçôes autônomas das classes trabalhadoras e eliminação física dos opositores.

\section{Referências}

ADORNO, Theodor. Educação e Emancipação. Trad. WolfgangLeo Maar. - Rio de Janeiro: Paz e Terra, 1995.

ADORNO, Theodor; HORKHEIMER, Max. Dialetica do esclarecimento: fragmentos filosóficos. Trad. Guido Antonio de Almeida - Rio de Janeiro: Zahar, 1985.

ALTUSSER, Louis. Aparelhos Ideológicos de Estado. $3^{\mathrm{a}}$ edição. Rio de Janeiro: Edições Graal, 1987.

AGOSTINI, Renata. MEC cortará verbas de universidades por balburdia e já enquadra UnB, UFF e UFBA. In. Estadão. Publicado em 30 abr. 2019. Disponível em https://educacao.estadao.com.br/noticias/geral, mec-cortara-verba-de-universidade-por-balburdiae-ja-mira-unb-uff-e-ufba, 70002809579 Acesso em 07 jan. 2020. 
AGOSTINI, Renata. MEC vai cortar recursos da Capes e federais terão mesmo orçamento. In. ESTAD ÃO. Publicado em 02 set. 2019. Disponível em https://educacao.estadao.com.br/noticias/geral,mec-vai-cortar-recurso-da-capes-e-federais-teraomesmo-orcamento, 70002992566 Acesso em 12 jan. 2020.

ALFANO, Bruno; VENTURA, Manoel. 'Zebras gordas' de Weintraub, professores universitários que ganham o teto são minoria. Publicado em 07 out. 2019. Atualizado em 09 out. 2019. In. O Globo. Disponível em https://oglobo.globo.com/sociedade/educacao/zebras-gordas-de-weintraubprofessores-universitarios-que-ganham-teto-sao-minoria-24000307 Acesso em 11 já. 2020.

BARRUCHO Luis. Demissão do chefe do INPE é alarmante, diz diretor do centro da NASA. In. BBC. Publicado em 07 ago. 2019. Disponível em https://www.bbc.com/portuguese/brasil49256294 Acesso em 12 jan. 2020.

BERTONI, Estêvão. Os efeitos do desbloqueio tardio de verbas para as universidades. In. NEXO. Publicado em 22 out. 2019. Disponível em

https://www.nexojornal.com.br/expresso/2019/10/22/Os-efeitos-do-desbloqueio-tardio-deverbas-para-as-universidades Acesso em 07 jan. 2020.

BLAS, Garcia; GALVEZ, José Maria Jimenez. Os ‘indignados’ da Espanha avaliam seu legado quatro anos depois. In. El País. Publicado em 15 mai. 2015. Disponível em https://brasil.elpais.com/brasil/2015/05/15/internacional/1431679318 951340.html Acesso em 11 jan. 2020.

BRANDÃO, Marcelo. Novo partido de Bolsonaro é registrado em cartório. In. Agência Brasil. Publicado em 05 dez. 2019. Disponível em http://agenciabrasil.ebc.com.br/politica/noticia/201912/novo-partido-de-bolsonaro-tem-sua-criacao-registrada-em-cartorio Acesso em 09 jan. 2020.

BRASIL DE FATO. 30M: Atos em defesa da educação terminam com chamado à Greve Geral de 14 de junho. Publicado em 30 mai. 2019. Disponível em https://www.brasildefato.com.br/2019/05/30/30matos-em-defesa-da-educacao-terminam-com-chamado-a-greve-geral-de-14-de-junho/Acesso em 11 jan. 2020.

CARTA CAPITAL. Bolsonaro afirma que concursos públicos selecionam somente pessoas de esquerda. Publicado em 12 jan. 2020. Disponível em https://www.cartacapital.com.br/politica/bolsonaro-afirma-queconcursos-publicos-selecionam-pessoas-de-esquerda/ Acesso em 12 jan. 2020.

CARTA CAPITAL. Quem é Marcos Pontes, indicado como Ministro da Ciência e Tecnologia. Publicado em 31 out. 2018. Disponível em https://www.cartacapital.com.br/politica/quem-emarcos-pontes-astronauta-brasieiro-confirmado-como-ministro-da-ciencia/ Acesso em 12 jan. 2020.

ÉPOCA NEGÓCIOS. Bolsonaro: Dinheiro retirado de universidades será investido em educação básica. Publicado em 03 mai. 2019. Disponível em https://epocanegocios.globo.com/Brasil/noticia/2019/05/bolsonaro-dinheiro-retirado-deuniversidades-sera-investido-em-ensino-basico.html Acesso em 07 jan. 2020.

ESCOBAR, Herton. Pesquisadores alertam para risco de desmonte da ciência no Brasil. In. JORNAL DA USP. Publicado em 11 out. 2019. Disponível em https://jornal.usp.br/universidade/politicas-cientificas/pesquisadores-alertam-para-risco-dedesmonte-da-ciencia-no-brasil// Acesso em 12 jan. 2020.

EXAME. MEC contraria discurso e tira verba da educaşão básica, além de faculdades. Publicada em 04 mai. 2019. Disponível em https://exame.abril.com.br/brasil/mec-contraria-discurso-e-tira-verba-daeducacao-basica-alem-de-faculdades/ Acesso em 09 jan. 2020.

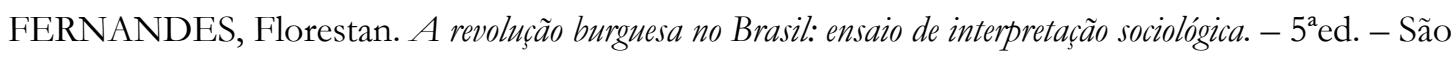
Paulo: Globo, 2005.

FILHO, João. Novo projeto de poder de Bolsonaro, a Aliança pelo Brasil é o primeiro partido neofascista do país. In. The Intercept. Publicado em 17 nov. 2019. Disponível em https://theintercept.com/2019/11/17/alianca-pelo-brasil-bolsonaro-neofascista/ Acesso em 09 jan. 2020. 
FREITAS, Raquel; ZUBA, Fernando. Reitor e vice-reitora da UFMG são alvo de condução coercitiva da PF em operação contra desvio de recursos em BH. In. G1. Publicado em 06 dez. 2017. Disponível em https://g1.globo.com/mg/minas-gerais/noticia/reitor-e-vice-reitora-daufmg-sao-alvo-de-conducao-coercitiva-da-pf-em-operacao-contra-desvio-de-recursos-em-bh.ghtml Acesso em 06 jan. 2020.

GRAMSCI, Antonio. Os cadernos do cárcere. Introdução ao estudo da filosofia. A filosofia de Benedetto Croce. (vol.1); $3^{\mathrm{a} e d}$. Trad. Carlos Nelson Coutinho. - Rio de Janeiro: Civilização Brasileira, 2004.

Os cadernos do cárcere. Os intelectuais. O princípio educativo. Jornalismo. (vol.2); Trad. Carlos Nelson Coutinho. $3^{\mathrm{a}}$ ed. - Rio de Janeiro: Civilização Brasileira, 2004.

- Os cadernos do cárcere. Maquiavel. Notas sobre o Estado e a política. (vol.3); Trad. Carlos Nelson Coutinho, Luiz Sérgio Henrique, Marco Aurélio Nogueira. - Rio de Janeiro: Civilização Brasileira, 2007.

Os cadernos do cárcere. Temas da Cultura. Ação Católica. Americanismo e fordismo. (vol.4) Trad. Carlos Nelson Coutinho, Luiz Sérgio Henrique. - Rio de Janeiro: Civilização Brasileira, 2001. Os cadernos do cárcere. Risorgimento. Notas sobre a história da Itália. (vol.5) Trad. Luiz Sérgio Henrique. - Rio de Janeiro: Civilização Brasileira, 2002.

- Os cadernos do cárcere. Literatura. Folclore. Gramática. (vol.6) Trad. Carlos Nelson Coutinho, Luiz Sérgio Henrique. Rio de Janeiro: Civilização Brasileira, 2002.

G1. Bolsonaro demite Vélez e nomeia Abraham Weintraub como ministro da educação. Publicado em 08 abr.2019. Disponível em https://g1.globo.com/politica/noticia/2019/04/08/planaltoanuncia-demissao-de-ricardo-velez-rodriguez-do-ministerio-da-educacao.ghtml Acesso em 03 jan. 2020.

G1. Bolsonaro edita MP que muda regras para escolha de reitores de universidades federais. Publicado em 25 dez. 2019. Disponível em https://g1.globo.com/jornalnacional/noticia/2019/12/25/bolsonaro-edita-mp-que-estabelece-regras-para-indicacao-dereitores-de-universidades-federais.ghtml Acesso em 07 jan. 2020.

G1. Future-se. Lei a integra da proposta do MEC sobre mudanças na gestão das universidades federais. Publicado em 17 jul.2019. Disponível em https://g1.globo.com/educacao/noticia/2019/07/17/future-se-leia-a-integra-da-proposta-do-mecsobre-mudancas-na-gestao-das-universidades-federais.ghtml Acesso em 03 jan. 2019.

G1. MEC abre nova consulta pública, sobre o Future-se. Publicado em 03 jan. 2020. Disponível em https://g1.globo.com/educacao/noticia/2020/01/03/mec-abre-nova-consulta-publica-sobre-Ofuture-se.ghtml Acesso em 12 jan. 2020.

G1. Morte de reitor da UFSC completa um ano; relatório da PF sobre a Ouvidos Moucos segue com o MPF. Publicado em 02 out. 2018. Disponível em https://g1.globo.com/sc/santacatarina/noticia/2018/10/02/morte-de-reitor-da-ufsc-completa-um-ano-relatorio-da-pf-sobre-aouvidos-moucos-segue-com-o-mpf.ghtml Acesso em 06 jan. 2020.

GAZETA DO POVO. Quem está por trás da greve geral de 14 de junho contra a reforma da Previdência. Publicado em 12 jun. 2019. Atualizado em 24 jun. 2019. Disponível em

https://www.gazetadopovo.com.br/republica/greve-geral-14-de-junho-previdencia-organizadoresparalisacao/Acesso em 11 já. 2020.

GREENWALD, Glenn; POUGY, Victor. Intercept e Veja publicam reportagem capa que mostra impropriedades em série - e inéditas de Sério Moro na Lava Jato. In. The Intercept. Publicado em 05 jul. 2019. Disponível em https://theintercept.com/2019/07/05/veja-conduta-moro-lavajato/ Acesso em 15 jan. 2020.

HABERMAS, Jürgen. Técnica e Ciência como "Ideologia". Trad. Felipe Gonçalves da Silva. - São Paulo: UNESP, 2014.

INSTITUTO LIBERAL. Os sinais de que o marxismo cultural é o ópio da universidade contemporânea. Publicado em 29 ago. 2017. Disponível em https://www.institutoliberal.org.br/blog/politica/os- 
sinais-de-que-o-marxismo-cultural-e-o-opio-da-universidade-contemporanea/ Acesso em 11 jan. 2020.

ISTO É. Ex-diretor do INPE, Ricardo Galvão, é escolhido uma das dez personalidades da ciência, pela 'Nature'. Publicado em 13 dez. 2019. Disponível em https://istoe.com.br/ricardo-galvao-eescolhido-uma-das-dez-personalidades-da-ciencia-pela-nature/ Acesso em 12 jan. 2020.

LAVAL, C. L'École n'est pas une entreprise. Paris: Éditions la Découverte, 2003.

LOPES, José Reinaldo. Universidades públicas produzem mais de $90 \%$ da pesquisa do país; resta saber até quando. In. Folba de São Paulo. Publicado em 21 abr. 2019. Disponível em https://www1.folha.uol.com.br/colunas/reinaldojoselopes/2019/04/universidades-publicasproduzem-mais-de-90-da-pesquisa-do-pais-resta-saber-ate-quando.shtml Acesso em 07 jan. 2020.

LUKÁCS, György. Para uma ontologia do ser social I. Trad. Carlos Nelson Coutinho, Mario Duayer e Nélio Schneider. - São Paulo: Boitempo, 2012.

Para uma ontologia do ser social II. Trad. Nélio Schneider, Ivo Tonet, Ronaldo Vielmi Fortes. - São Paulo: Boitempo, 2013.

MARTELLO, Alexandro. Divida pública sobe 2\% em setembro, para R \$ 4,15 trilhões, diz Tesouro Nacional. In. G1. Publicada em 29 out. 2019. Disponível em https://g1.globo.com/economia/noticia/2019/10/29/divida-publica-sobe-2percent-em-setembropara-r-415-trilhoes-diz-tesouro-nacional.ghtml Acesso em 09 jan. 2020.

MARX, Karl. O Capital: crítica da economia política. Livro I: o processo de producão do capital. Trad. Rubens Enderle. - São Paulo, Boitempo, 2013.

MEC. FUTURE-SE. Publicado em 23 jul.2019. Disponível em http://portal.mec.gov.br/ultimasnoticias/12-acoes-programas-e-projetos-637152388/78391-consulta-publica-tem-quase-15-milcadastrados-em-menos-de-uma-semana Acesso em 04 jan.2019.

MEC. Portaria no 1.701, de 30 de setembro de 2019. Disponível em http://www.in.gov.br/web/dou/-/portaria-n-1.701-de-30-de-setembro-de-2019-219146108 Acesso em 04 jan. 2020.

MEC/INEP. Instituto Nacional de Estudos e Pesquisas Educacionais Anísio Teixeira. Disponível em http://portal.inep.gov.br/web/guest/educacao-superior/indicadores-de-qualidade/resultados Acesso em 12 jan. 2020.

MÉSZÁROS, István. Para além do capital: rumo a uma teoria da transição. Trad. Paulo Cezar Castanheira, Sérgio Lessa. - São Paulo: Boitempo, 2011.

MORENO, Ana Carolina. Governo interveio em 6 de 12 nomeações de reitores em universidades federais, até agosto. In. G1. Publicado em 31 ago. 2019. Disponível em

https://g1.globo.com/educacao/noticia/2019/08/31/governo-interveio-em-6-de-12-nomeacoesde-reitores-de-universidades-federais-ate-agosto.ghtml Acesso em 07 jan. 2020.

MORENO, Ana Carolina. MEC reformula proposta do Future-se e diz que lançará nova consulta pública até o dia 28. In. G1. Publicado em 18 out.2019. Disponível em

https://g1.globo.com/educacao/noticia/2019/10/18/mec-reformula-proposta-do-future-se-e-dizque-lancara-nova-consulta-publica-ate-o-dia-28.ghtml Acesso em 04 jan.2020.

PATI, Camila. 36 universidades brasileiras entraram no maior ranking educacional do mundo. In. EXAME. Publicado em 26 set. 2018. Disponível em https://exame.abril.com.br/carreira/36universidades-do-brasil-entraram-no-maior-ranking-educacional-do-mundo/ Acesso em 12 jan. 2020.

PEREIRA, Luiz Carlos Bresser, 1934 - A Reforma do estado dos anos 90: lógica e mecanismos de controle. Brasília-DF: Ministério da Administração Federal e Reforma do Estado, 1997. Disponível em http://www.bresserpereira.org.br/documents/MARE/CadernosMare/CADERNO01.pdf Acesso em 07 jan. 2020. 
PINTO, Angela; CANOFRE, Fernanda. UNE convoca megaprotesto no dia 15 contra cortes na educação, mas descarta greve. In. Folha de São Paulo. Publicado em 10 mai. 2019. Disponível em https://www1.folha.uol.com.br/educacao/2019/05/une-convoca-mega-protesto-no-dia-15-contracortes-na-educacao-mas-descarta-greve.shtml Acesso em 11 jan. 2020.

PRESIDÊNCIA DA REPÚBLICA. Emenda Constitucional no 95, de 15 de dezembro de 2016. Disponível em http://www.planalto.gov.br/ccivil_03/constituicao/Emendas/Emc/emc95.htm Acesso em 06 jan. 2020.

PRESIDÊNCIA DA REPÚBLICA. Lei n. 9.637, de 15 de maio de 1998. Disponível em http://www.planalto.gov.br/ccivil_03/leis/19637.htm Acesso em 06 jan. 2020.

PRESIDÊNCIA DA REPÚBLICA. Constituição da República Federativa do Brasil de 1988. Disponível em http://www.planalto.gov.br/ccivil 03/constituicao/constituicao.htm Acesso em 06 jan.2020.

PRESIDÊNCIA DA REPÚBLICA. Constituição da República Federativa do Brasil de 1988. Disponível em http://www.planalto.gov.br/ccivil 03/constituicao/constituicao.htm Acesso em 06 jan.2020.

PRESIDÊNCIA DA REPÚBLICA. Decreto n ${ }^{\circ}$ 9.191, de 01 de novembro de 2017. Disponível em http://www.planalto.gov.br/ccivil 03/ ato2015-2018/2017/decreto/D9191.htm Acesso em 07 jan. 2020.

PRESIDÊNCIA DA REPÚBLICA. Decreto n ${ }^{\circ}$ 9.283, de 07 de fevereiro de 2018. Disponível em http://www.planalto.gov.br/ccivil 03/_Ato2015-2018/2018/Decreto/D9283.htm Acesso em 06 jan.2020.

PRESIDÊNCIA DA REPÚBLICA. Emenda Constitucional nº 19, de 04 de junho de 1998. Disponível em http://www.planalto.gov.br/ccivil_03/Constituicao/Emendas/Emc/emc19.htm Acesso em 09 jam. 2020.

PRESIDÊNCIA DA REPÚBLICA. Emenda Constitucional no 85, de 26 de fevereiro de 2015. Disponível em http://www.planalto.gov.br/ccivil 03/constituicao/Emendas/Emc/emc85.htm Acesso em 06 jan. 2020.

PRESIDÊNCIA DA REPÚBLICA. Lei no 10.973, de 02 de dezembro de 2004. Disponível em http://www.planalto.gov.br/ccivil_03/_ato2004-2006/2004/lei/110.973.htm Acesso em 06 jan. 2020.

PRESIDÊNCIA DA REPÚBLICA. Lei nº 11.079, de 30 de dezembro de 2004. Disponível em http://www.planalto.gov.br/ccivil_03/_Ato2004-2006/2004/Lei/L11079.htm Acesso em 09 jan. 2020.

PRESIDÊNCIA DA REPÚBLICA. Lei no 11.892, de 29 de dezembro de 2008. Disponível em http://www.planalto.gov.br/ccivil 03/_Ato2007-2010/2008/Lei/L11892.htm Acesso em 15 jan. 2020.

PRESIDÊNCIA DA REPÚBLICA. Lei no 12.527, de 18 de novembro de 2011. Disponível em http://www.planalto.gov.br/ccivil_03/_ato2011-2014/2011/lei/112527.htm Publicado em 07 jan. 2020.

PRESIDENCIA DA REPÚBLICA. Lei no 13.005, de 25 de junho de 2014. Disponível em http://www.planalto.gov.br/ccivil 03/ ato2011-2014/2014/lei/113005.htm Acesso em 06 jan.2020.

PRESIDÊNCIA DA REPÚBLICA. Lei no 13.243, de 11 de janeiro de 2016. Disponível em http://www.planalto.gov.br/ccivil 03/ Ato2015-2018/2016/Lei/L13243.htm Acesso em 06 jan. 2020.

PRESIDÊNCIA DA REPÚBLICA. Lei no 13.260, de 16 de março de 2016. Disponível em http://www.planalto.gov.br/ccivil 03/ Ato2015-2018/2016/Lei/L13260.htm Acesso em 12 jan. 2020. 
PRESIDÊNCIA DA REPÚBLICA. Lei no 13.800, de 04 de janeiro de 2019. Disponível em http://www.planalto.gov.br/ccivil 03/ Ato2019-2022/2019/Lei/L13800.htm Acesso em 06 jan. 2020.

PRESIDÊNCIA DA REPÚBLICA. Lei no 8.958, de 20 de dezembro de 1994. Disponível em http://www.planalto.gov.br/ccivil 03/LEIS/L8958.htm Acesso em 09 jan. 2020.

PRESIDÊNCIA DA REPÚBLICA. Lei no 9.394, de 20 de dezembro de 1996. Disponível em http://www.planalto.gov.br/ccivil 03/leis/19394.htm Acesso em 06 jan. 2020.

PRESIDÊNCIA DA REPÚBLICA. Medida Provisória nº 914, de 24 de dezembro de 2019. Disponível em http://www.planalto.gov.br/ccivil_03/ ato2019-2022/2019/Mpv/mpv914.htm Acesso em 12 jan. 2020.

RBA. Temer desrespeita eleição e não nomeia reitor mais votado na UFABC. Publicado em 12 mar. 2018. Disponível em https://www.redebrasilatual.com.br/educacao/2018/03/temerdesrespeita-eleicao-interna-e-suspende-nomeacao-de-reitor-mais-votado-na-ufabc/ Acesso em 07 jan. 2020.

RODRIGUES, Mateus. Convocado pela Câmara, Weintraub reafirma que há produção de drogas em universidades federais. In. G1. Publicado em 11 dez. 2019. Disponível em https://g1.globo.com/educacao/noticia/2019/12/11/weintraub-reafirma-existencia-deplantacoes-de-maconha-e-laboratorios-de-droga-nas-universidades-federais-em-comissao-nacamara.ghtml Acesso em 11 jan. 2020.

SENADO. Art. 37. In. Constituição Federal. Publicado em 26 jun. 2019. Disponível em https://www.senado.leg.br/atividade/const/con1988/con1988 26.06.2019/art 37 asp Acesso em 11 jan. 2020.

SHALDERS, André; ALVIM, Mariana. A crise que derrubou o ministro Vélez em 9 tuites. In. BBC NEWS. Publicado em 08 abr.2019. Disponível em https://www.bbc.com/portuguese/geral$\underline{47742413}$ Acesso em 03 jan.2020.

SILVA, Marcelo Lira. A linguagem do consenso nos marcos da regressão cultural. Publicada em 07 ago. 2014. Disponível em

https://www.marilia.unesp.br/Home/PosGraduacao/CienciasSociais/Dissertacoes/silva ml do mar.pd Acesso em 09 jan. 2020.

SILVA, Marcelo Lira. Coup d’État e exclusivismo político-educacional: uma análise da Medida Provisória 746/2016. In. Germinal: Marxismo e Educação em Debate, Salvador, v. 9, n. 3, p. 182-210, dez. 2017. Disponível em

https://portalseer.ufba.br/index.php/revistagerminal/article/view/23726/15289 Acesso em 09 jan. 2020.

SILVA, Marcelo Lira. Notas gramscianas: Golpe de Estado e luta de classes no Brasil do século XXI. In. Movimentação, Dourados, v.04, nº7, p.01-32, 2017. Disponível em http://ojs.ufgd.edu.br/index.php/movimentacao/article/view/8427/4482 Acesso em 09 jan. 2020.

SILVA, Marcelo Lira. A moral deontológica como síntese da alma e das formas do Estado Liberal. Revista Aurora, v.05, n02, pp.11-40, jan.-jun. 2012. Disponível em file:///C:/Users/Marcelo\%20Lira/Downloads/2349-Texto\%20do\%20artigo-8128-1-1020120705.pdf Acesso em 08 jan. 2020.

SUGIMOTO, Luiz. 'O CNPq foi o ponto de partida para o desenvolvimento da ciência no Brasil'. In. JORNAL DA UNICAMP. Publicado em 02 out. 2019. Disponível em https://www.unicamp.br/unicamp/ju/noticias/2019/10/02/o-cnpq-foi-o-ponto-de-partida-parao-desenvolvimento-da-ciencia-no-brasil Acesso em 12 jan. 2020.

SUPREMO TRIBUNAL FEDERAL. Publicado em 16 abr. 2015. Disponível em http://redir.stf.jus.br/paginadorpub/paginador.jsp?docTP=TP\&docID=10006961 Acesso em 07 jan.2020. 
TENENTE, Luiza; FIGUEIREDO, Patrícia. Entenda o corte de verba das universidades federais e saiba como são os orçamentos das 10 maiores. In. G1. Publicado em 15 mai. 2019. Disponível em https://g1.globo.com/educacao/noticia/2019/05/15/entenda-o-corte-de-verba-das-universidadesfederais-e-saiba-como-sao-os-orcamentos-das-10-maiores.ghtml Acesso em 06 jan. 2020.

VENAGLIA, Guilherme. Abraham Weintraub é o novo ministro da educação. In. VEJA.

Publicado em 08 abr. 2019. Disponível em https://veja.abril.com.br/politica/abraham-weintraube-o-novo-ministro-da-educacao/Acesso em 09 jan. 2020.

VIEIRA, Victor. Governo quer cortar 45\% das verbas das Universidades Federais. Publicado em 11 ago. 2016. In. Exame. Disponível em https://exame.abril.com.br/brasil/governo-quer-cortar-45da-verba-das-universidades-federais/ Acesso em 07 jan. 2020.

\section{Notas:}

${ }^{1}$ Professor Efetivo de Sociologia do Instituto Federal de Educação, Ciência e Tecnologia de Goiás/Campus Goiânia, no qual desenvolve atividades de ensino-pesquisa-extensão, em diversos níveis e modalidades, desde abril de 2014. Líder do Núcleo de Estudos e Pesquisas Avançadas - Ética e Política Emancipatória (NEPA-EPE). Professor-pesquisador da Especialização em Políticas e Gestão da Educação Profissional e Tecnológica/Campus Goiânia, na qual leciona, desenvolve pesquisa e orienta. Orcid: https://orcid.org/0000-0003-3457-0864 Email: marcelo.silva@ifg.edu.br

2 PRESIDÊNCIA DA REPÚBLICA. Lei $\mathrm{n}^{\mathrm{o}}$ 13.260, de 16 de março de 2016. Disponível em http://www.planalto.gov.br/ccivil 03/ Ato2015-2018/2016/Lei/L13260.htm Acesso em 12 jan. 2020.

${ }^{3}$ EXAME. MEC contraria discurso e tira verba da educaşão básica, além de faculdades. Publicada em 04 mai. 2019. Disponível em https://exame.abril.com.br/brasil/mec-contraria-discurso-e-tira-verba-da-educacao-basica-alem-de-faculdades/ Acesso em 09 jan. 2020.

4 MARTELLO, Alexandro. Divida pública sobe 2\% em setembro, para R\$ 4,15 trilhões, diz Tesouro Nacional. In. G1. Publicada em 29 out. 2019. Disponível em https://g1.globo.com/economia/noticia/2019/10/29/divida-publica-sobe2percent-em-setembro-para-r-415-trilhoes-diz-tesouro-nacional.ghtml Acesso em 09 jan. 2020.

5 BRANDÃO, Marcelo. Novo partido de Bolsonaro é registrado em cartório. In. Agência Brasil. Publicado em 05 dez. 2019. Disponível em http://agenciabrasil.ebc.com.br/politica/noticia/2019-12/novo-partido-de-bolsonaro-tem-sua-criacaoregistrada-em-cartorio Acesso em 09 jan. 2020.

${ }^{6}$ FILHO, João. Novo projeto de poder de Bolsonaro, a Aliança pelo Brasil é o primeiro partido neofascista do país. In. The Intercept. Publicado em 17 nov. 2019. Disponível em https://theintercept.com/2019/11/17/alianca-pelo-brasilbolsonaro-neofascista/ Acesso em 09 jan. 2020.

${ }^{7}$ SHALDERS, André; ALVIM, Mariana. A crise que derrubou o ministro Vélez em 9 tuites. In. BBC NEWS. Publicado em 08 abr.2019. Disponível em https://www.bbc.com/portuguese/geral-47742413 Acesso em 03 jan.2020.

8 G1. Bolsonaro demite Vélez e nomeia Abraham Weintraub como ministro da educação. Publicado em 08 abr.2019. Disponível em https://g1.globo.com/politica/noticia/2019/04/08/planalto-anuncia-demissao-de-ricardo-velezrodriguez-do-ministerio-da-educacao.ghtml Acesso em 03 jan. 2020.

9 VENAGLIA, Guilherme. Abraham Weintraub é o novo ministro da educação. In. VEJA. Publicado em 08 abr. 2019. Disponível em https://veja.abril.com.br/politica/abraham-weintraub-e-o-novo-ministro-da-educacao/ Acesso em 09 jan. 2020.

10 CARTA CAPITAL. Quem é Marcos Pontes, indicado como Ministro da Ciência e Tecnologia. Publicado em 31 out. 2018. Disponível em https://www.cartacapital.com.br/politica/quem-e-marcos-pontes-astronauta-brasieiroconfirmado-como-ministro-da-ciencia/ Acesso em 12 jan. 2020.

11 BARRUCHO Luis. Demissão do chefe do INPE é alarmante, diz diretor do centro da NASA. In. BBC. Publicado em 07 ago. 2019. Disponível em https://www.bbc.com/portuguese/brasil-49256294 Acesso em 12 jan. 2020.

12 ISTO É. Ex-diretor do INPE, Ricardo Galvão, é escolhido uma das dez personalidades da ciência, pela 'Nature'. Publicado em 13 dez. 2019. Disponível em https://istoe.com.br/ricardo-galvao-e-escolhido-uma-das-dezpersonalidades-da-ciencia-pela-nature/ Acesso em 12 jan. 2020.

${ }^{13}$ G1. Future-se. Lei a integra da proposta do MEC sobre mudanças na gestão das universidades federais. Publicado em 17 jul.2019. Disponível em https://g1.globo.com/educacao/noticia/2019/07/17/future-se-leia-a-integra-da-proposta-domec-sobre-mudancas-na-gestao-das-universidades-federais.ghtml Acesso em 03 jan. 2019.

14 PRESIDÊNCIA DA REPÚBLICA. Decreto $\mathrm{n}^{\mathrm{o}}$ 9.191, de 01 de novembro de 2017. Disponível em http://www.planalto.gov.br/ccivil 03/ ato2015-2018/2017/decreto/D9191.htm Acesso em 07 jan. 2020.

15 SUGIMOTO, Luiz. 'O CNPq foi o ponto de partida para o desenvolvimento da ciência no Brasil'. In. JORNAL DA UNICAMP. Publicado em 02 out. 2019. Disponível em https://www.unicamp.br/unicamp/ju/noticias/2019/10/02/ocnpq-foi-o-ponto-de-partida-para-o-desenvolvimento-da-ciencia-no-brasil Acesso em 12 jan. 2020. 
16 AGOSTINI, Renata. MEC vai cortar recursos da Capes e federais terão mesmo orçamento. In. ESTAD AOO. Publicado em 02 set. 2019. Disponível em https://educacao.estadao.com.br/noticias/geral,mec-vai-cortar-recurso-da-capes-efederais-terao-mesmo-orcamento, 70002992566 Acesso em 12 jan. 2020.

17 ESCOBAR, Herton. Pesquisadores alertam para risco de desmonte da ciência no Brasil. In. JORNAL DA USP. Publicado em 11 out. 2019. Disponível em https://jornal.usp.br/universidade/politicas-cientificas/pesquisadoresalertam-para-risco-de-desmonte-da-ciencia-no-brasil// Acesso em 12 jan. 2020.

18 MEC. FUTURE-SE. Publicado em 23 jul.2019. Disponível em http://portal.mec.gov.br/ultimas-noticias/12-acoesprogramas-e-projetos-637152388/78391-consulta-publica-tem-quase-15-mil-cadastrados-em-menos-de-uma-semana Acesso em 04 jan.2019.

19 PRESIDÊNCIA DA REPÚBLICA. Constituição da República Federativa do Brasil de 1988. Disponível em http://www.planalto.gov.br/ccivil 03/constituicao/constituicao.htm Acesso em 06 jan.2020.

${ }^{20}$ MEC. Portaria no 1.701, de 30 de setembro de 2019. Disponível em http://www.in.gov.br/web/dou/-/portaria-n-1.701de-30-de-setembro-de-2019-219146108 Acesso em 04 jan. 2020.

${ }^{21}$ Art. $4^{\circ}$ O Grupo de Especialistas Jurídicos será composto pelos seguintes membros da Advocacia-Geral da União: I Diana Guimarães Azin - matrícula SIAPE no 1480008; II - Fernanda Raso Zamorano - matrícula SIAPE nº 1041175; III - José Aparecido Buffon - matrícula SIAPE no 0270645; IV - Ludmila Meira Maia Dias - matrícula SIAPE no 1635599; e V - Saulo Pinheiro de Queiroz - matrícula SIAPE no 1729364 . Art. $5^{\circ}$ A coordenação do Grupo de Especialistas ficará a cargo da Advogada da União Fernanda Raso Zamorano. Parágrafo único. Compete à Coordenadora: I - definir o plano de atividades e gerenciar seus resultados; II - conduzir os trabalhos propostos; e III - apresentar as conclusões e o material produzido ao Secretário de Educação Superior e ao Secretário de Educação Profissional e Tecnológica do Ministério da Educação. (MEC. Portaria no 1.701, de 30 de setembro de 2019. Disponível em http://www.in.gov.br/web/dou/Lportaria-n-1.701-de-30-de-setembro-de-2019-219146108 Acesso em 04 jan. 2020).

22 MORENO, Ana Carolina. MEC reformula proposta do Future-se e diz que lançará nova consulta pública até o dia 28. In. G1. Publicado em 18 out.2019. Disponível em https://g1.globo.com/educacao/noticia/2019/10/18/mec-reformulaproposta-do-future-se-e-diz-que-lancara-nova-consulta-publica-ate-o-dia-28.ghtml Acesso em 04 jan.2020.

23 SENADO. Art. 37. In. Constituição Federal. Publicado em 26 jun. 2019. Disponível em https://www.senado.leg.br/atividade/const/con1988/con1988 26.06.2019/art 37 .asp Acesso em 11 jan. 2020.

24 ALFANO, Bruno; VENTURA, Manoel. 'Zebras gordas' de Weintraub, professores universitários que ganham o teto são minoria. Publicado em 07 out. 2019. Atualizado em 09 out. 2019. In. O Globo. Disponível em https://oglobo.globo.com/sociedade/educacao/zebras-gordas-de-weintraub-professores-universitarios-que-ganhamteto-sao-minoria-24000307 Acesso em 11 já. 2020.

25 G1. MEC abre nova consulta pública, sobre o Future-se. Publicado em 03 jan. 2020. Disponível em https://g1.globo.com/educacao/noticia/2020/01/03/mec-abre-nova-consulta-publica-sobre-o-future-se.ghtml Acesso em 12 jan. 2020.

26 PRESIDENCIA DA REPÚBLICA. Lei $\mathrm{n}^{\circ}$ 13.005, de 25 de junho de 2014 . Disponível em http://www.planalto.gov.br/ccivil 03/ ato2011-2014/2014/lei/113005.htm Acesso em 06 jan.2020.

27 PRESIDÊNCIA DA REPÚBLICA. Lei $\mathrm{n}^{\circ}$ 8.958, de 20 de dezembro de 1994 . Disponível em http://www.planalto.gov.br/ccivil 03/LEIS/L8958.htm Acesso em 09 jan. 2020.

28 PRESIDÊNCIA DA REPÚBLICA. Lei $\mathrm{n}^{\circ}$ 13.243, de 11 de janeiro de 2016. Disponível em http://www.planalto.gov.br/ccivil 03/ Ato2015-2018/2016/Lei/L13243.htm Acesso em 06 jan. 2020.

29 PRESIDÊNCIA DA REPÚBLICA. Lei $\mathrm{n}^{\circ}$ 10.973, de 02 de dezembro de 2004. Disponível em http://www.planalto.gov.br/ccivil 03/ ato2004-2006/2004/lei/110.973.htm Acesso em 06 jan. 2020.

30 PRESIDÊNCIA DA REPÚBLICA. Lei $\mathrm{n}^{\circ}$ 11.079, de 30 de dezembro de 2004. Disponível em http://www.planalto.gov.br/ccivil 03/ Ato2004-2006/2004/Lei/L11079.htm Acesso em 09 jan. 2020.

31 PRESIDÊNCIA DA REPÚBLICA. Emenda Constitucional $\mathrm{n}^{\circ}$ 85, de 26 de fevereiro de 2015. Disponível em http://www.planalto.gov.br/ccivil 03/constituicao/Emendas/Emc/emc85.htm Acesso em 06 jan. 2020.

32 PRESIDÊNCIA DA REPÚBLICA. Decreto $\mathrm{n}^{\circ}$ 9.283, de 07 de fevereiro de 2018. Disponível em http://www.planalto.gov.br/ccivil 03/ Ato2015-2018/2018/Decreto/D9283.htm Acesso em 06 jan.2020.

33 PRESIDÊNCIA DA REPÚBLICA. Constituição da República Federativa do Brasil de 1988. Disponível em http://www.planalto.gov.br/ccivil 03/constituicao/constituicao.htm Acesso em 06 jan.2020.

34 PRESIDÊNCIA DA REPÚBLICA. Lei $\mathrm{n}^{\circ}$ 9.394, de 20 de dezembro de 1996. Disponível em http://www.planalto.gov.br/ccivil 03/leis/19394.htm Acesso em 06 jan. 2020.

35 PRESIDÊNCIA DA REPÚBLICA. Lei $\mathrm{n}^{\circ}$ 11.892, de 29 de dezembro de 2008. Disponível em http://www.planalto.gov.br/ccivil 03/ Ato2007-2010/2008/Lei/L11892.htm Acesso em 15 jan. 2020.

36 PRESIDÊNCIA DA REPÚBLICA. Emenda Constitucional no 95, de 15 de dezembro de 2016. Disponível em http://www.planalto.gov.br/ccivil 03/constituicao/Emendas/Emc/emc95.htm Acesso em 06 jan. 2020.

37 TENENTE, Luiza; FIGUEIREDO, Patrícia. Entenda o corte de verba das universidades federais e saiba como são os orçamentos das 10 maiores. In. G1. Publicado em 15 mai. 2019. Disponível em https://g1.globo.com/educacao/noticia/2019/05/15/entenda-o-corte-de-verba-das-universidades-federais-e-saibacomo-sao-os-orcamentos-das-10-maiores.ghtml Acesso em 06 jan. 2020.

38 PRESIDÊNCIA DA REPÚBLICA. Lei n. 9.637, de 15 de maio de 1998. Disponível em http://www.planalto.gov.br/ccivil 03/leis/19637.htm Acesso em 06 jan. 2020.

Germinal: Marxismo e Educação em Debate, Salvador, v. 11, n. 3, p. 88-122, dę. 2019. ISSN: 2175-5604 
39 PRESIDÊNCIA DA REPÚBLICA. Lei $\mathrm{n}^{\mathrm{o}}$ 13.800, de 04 de janeiro de 2019. Disponível em http://www.planalto.gov.br/ccivil 03/ Ato2019-2022/2019/Lei/L13800.htm Acesso em 06 jan. 2020.

$40 \mathrm{MEC} / \mathrm{INEP}$. Instituto Nacional de Estudos e Pesquisas Educacionais Anísio Teixeira. Disponível em http://portal.inep.gov.br/web/guest/educacao-superior/indicadores-de-qualidade/resultados Acesso em 12 jan. 2020.

41 PATI, Camila. 36 universidades brasileiras entraram no maior ranking educacional do mundo. In. EXAME. Publicado em 26 set. 2018. Disponível em https://exame.abril.com.br/carreira/36-universidades-do-brasil-entraram-no-maiorranking-educacional-do-mundo/Acesso em 12 jan. 2020.

42 PRESIDÊNCIA DA REPÚBLICA. Emenda Constitucional no 19, de 04 de junho de 1998. Disponível em http://www.planalto.gov.br/ccivil 03/Constituicao/Emendas/Emc/emc19.htm Acesso em 09 jam. 2020.

43 PEREIRA, Luiz Carlos Bresser, 1934 - A Reforma do estado dos anos 90: lógica e mecanismos de controle. - Brasília-DF: Ministério da Administração Federal e Reforma do Estado, 1997. Disponível em http://www.bresserpereira.org.br/documents/MARE/CadernosMare/CADERNO01.pdf Acesso em 07 jan. 2020.

${ }^{44}$ INSTITUTO LIBERAL. Os sinais de que o marxismo cultural é o ópio da universidade contemporânea. Publicado em 29 ago. 2017. Disponível em https://www.institutoliberal.org.br/blog/politica/os-sinais-de-que-o-marxismo-cultural-e-o-opio-dauniversidade-contemporanea/ Acesso em 11 jan. 2020.

45 RODRIGUES, Mateus. Convocado pela Câmara, Weintraub reafirma que há produção de drogas em universidades federais. In. G1. Publicado em 11 dez. 2019. Disponível em https://g1.globo.com/educacao/noticia/2019/12/11/weintraub-reafirma-existencia-de-plantacoes-de-maconha-elaboratorios-de-droga-nas-universidades-federais-em-comissao-na-camara.ghtml Acesso em 11 jan. 2020.

46 G1. Morte de reitor da UFSC completa um ano; relatório da PF sobre a Ouvidos Moucos segue com o MPF. Publicado em 02 out. 2018. Disponível em https://g1.globo.com/sc/santa-catarina/noticia/2018/10/02/morte-de-reitor-da-ufsc-completaum-ano-relatorio-da-pf-sobre-a-ouvidos-moucos-segue-com-o-mpf.ghtml Acesso em 06 jan. 2020.

47 FREITAS, Raquel; ZUBA, Fernando. Reitor e vice-reitora da UFMG são alvo de condução coercitiva da PF em operação contra desvio de recursos em BH. In. G1. Publicado em 06 dez. 2017. Disponível em https://g1.globo.com/mg/minasgerais/noticia/reitor-e-vice-reitora-da-ufmg-sao-alvo-de-conducao-coercitiva-da-pf-em-operacao-contra-desvio-derecursos-em-bh.ghtml Acesso em 06 jan. 2020.

48 GREENWALD, Glenn; POUGY, Victor. Intercept e Veja publicam reportagem capa que mostra impropriedades em série - e inéditas de Sério Moro na Lava Jato. In. The Intercept. Publicado em 05 jul. 2019. Disponível em https://theintercept.com/2019/07/05/veja-conduta-moro-lavajato/ Acesso em 15 jan. 2020.

49 AGOSTINI, Renata. MEC cortará verbas de universidades por balburdia e já enquadra UnB, UFF e UFBA. In. Estadão. Publicado em 30 abr. 2019. Disponível em https://educacao.estadao.com.br/noticias/geral,mec-cortara-verba-deuniversidade-por-balburdia-e-ja-mira-unb-uff-e-ufba, 70002809579 Acesso em 07 jan. 2020.

50 PRESIDÊNCIA DA REPÚBLICA. Lei $\mathrm{n}^{\circ}$ 12.527, de 18 de novembro de 2011. Disponível em http://www.planalto.gov.br/ccivil 03/ ato2011-2014/2011/lei/112527.htm Publicado em 07 jan. 2020.

51 SUPREMO TRIBUNAL FEDERAL. Publicado em 16 abr. 2015. Disponível em http://redir.stf.jus.br/paginadorpub/paginador.jsp?docTP=TP\&docID=10006961 Acesso em 07 jan.2020.

52 LOPES, José Reinaldo. Universidades públicas produzem mais de $90 \%$ da pesquisa do país; resta saber até quando. In. Folha de São Paulo. Publicado em 21 abr. 2019. Disponível em https://www1.folha.uol.com.br/colunas/reinaldojoselopes/2019/04/universidades-publicas-produzem-mais-de-90-dapesquisa-do-pais-resta-saber-ate-quando.shtml Acesso em 07 jan. 2020.

53 VIEIRA, Victor. Governo quer cortar 45\% das verbas das Universidades Federais. Publicado em 11 ago. 2016. In. Exame. Disponível em https://exame.abril.com.br/brasil/governo-quer-cortar-45-da-verba-das-universidades-federais/ Acesso em 07 jan. 2020.

${ }^{54}$ RBA. Temer desrespeita eleição e não nomeia reitor mais votado na UFABC. Publicado em 12 mar. 2018. Disponível em https://www.redebrasilatual.com.br/educacao/2018/03/temer-desrespeita-eleicao-interna-e-suspende-nomeacaode-reitor-mais-votado-na-ufabc/ Acesso em 07 jan. 2020.

55 ÉPOCA NEGÓCIOS. Bolsonaro: Dinheiro retirado de universidades será investido em educação básica. Publicado em 03 mai. 2019. Disponível em https://epocanegocios.globo.com/Brasil/noticia/2019/05/bolsonaro-dinheiro-retiradode-universidades-sera-investido-em-ensino-basico.html Acesso em 07 jan. 2020.

56 BERTONI, Estêvão. Os efeitos do desbloqueio tardio de verbas para as universidades. In. NEXO. Publicado em 22 out. 2019. Disponível em https://www.nexojornal.com.br/expresso/2019/10/22/Os-efeitos-do-desbloqueio-tardio-deverbas-para-as-universidades Acesso em 07 jan. 2020.

${ }^{57}$ MORENO, Ana Carolina. Governo interveio em 6 de 12 nomeações de reitores em universidades federais, até agosto. In. G1. Publicado em 31 ago. 2019. Disponível em https://g1.globo.com/educacao/noticia/2019/08/31/governointerveio-em-6-de-12-nomeacoes-de-reitores-de-universidades-federais-ate-agosto.ghtml Acesso em 07 jan. 2020.

58 G1. Bolsonaro edita MP que muda regras para escolha de reitores de universidades federais. Publicado em 25 dez. 2019. Disponível em https://g1.globo.com/jornal-nacional/noticia/2019/12/25/bolsonaro-edita-mp-que-estabelece-regraspara-indicacao-de-reitores-de-universidades-federais.ghtml Acesso em 07 jan. 2020.

59 CARTA CAPITAL. Bolsonaro afirma que concursos públicos selecionam somente pessoas de esquerda. Publicado em 12 jan. 2020. Disponível em https://www.cartacapital.com.br/politica/bolsonaro-afirma-que-concursos-publicos-selecionampessoas-de-esquerda/ Acesso em 12 jan. 2020. 
60 PRESIDÊNCIA DA REPÚBLICA. Medida Provisória no 914, de 24 de dezembro de 2019. Disponível em http://www.planalto.gov.br/ccivil 03/ ato2019-2022/2019/Mpv/mpv914.htm Acesso em 12 jan. 2020.

${ }^{61}$ PINTO, Angela; CANOFRE, Fernanda. UNE convoca megaprotesto no dia 15 contra cortes na educação, mas descarta greve. In. Folha de São Paulo. Publicado em 10 mai. 2019. Disponível em https://www1.folha.uol.com.br/educacao/2019/05/une-convoca-mega-protesto-no-dia-15-contra-cortes-na-educacaomas-descarta-greve.shtml Acesso em 11 jan. 2020.

62 BRASIL DE FATO. 30M: Atos em defesa da educação terminam com chamado à Greve Geral de 14 de junho. Publicado em 30 mai. 2019. Disponível em https://www.brasildefato.com.br/2019/05/30/30m-atos-em-defesa-da-educacao-terminam-comchamado-a-greve-geral-de-14-de-junho/ Acesso em 11 jan. 2020.

${ }^{63}$ BLAS, Garcia; GALVEZ, José Maria Jimenez. Os 'indignados’ da Espanha avaliam seu legado quatro anos depois. In. El País. Publicado em $15 \quad$ mai. $2015 . \quad$ Disponível $\mathrm{em}$ https://brasil.elpais.com/brasil/2015/05/15/internacional/1431679318 951340.html Acesso em 11 jan. 2020.

${ }^{64}$ GAZETA DO POVO. Quem está por trás da greve geral de 14 de junbo contra a reforma da Previdência. Publicado em 12 jun. 2019. Atualizado em 24 jun. 2019. Disponível em https://www.gazetadopovo.com.br/republica/greve-geral-14-dejunho-previdencia-organizadores-paralisacao/ Acesso em 11 já. 2020.

Recebido em: 15.01.2020

Publicado em: 20.04.2020 